Portland State University

PDXScholar

6-29-1989

\title{
The Congress of Berlin of 1878: Its Origins and Consequences
}

Kenneth Allen Shafer

Portland State University

Follow this and additional works at: https://pdxscholar.library.pdx.edu/open_access_etds

Part of the European History Commons, and the Political History Commons Let us know how access to this document benefits you.

\section{Recommended Citation}

Shafer, Kenneth Allen, "The Congress of Berlin of 1878: Its Origins and Consequences" (1989).

Dissertations and Theses. Paper 3927.

https://doi.org/10.15760/etd.5811

This Thesis is brought to you for free and open access. It has been accepted for inclusion in Dissertations and Theses by an authorized administrator of PDXScholar. Please contact us if we can make this document more accessible: pdxscholar@pdx.edu. 
AN ABSTRACT OF THE THESIS OF Kenneth Allen Shafer for the Master of Arts in History presented June 29, 1989.

Title: The Congress of Berlin of 1878:

Its Origins and Consequences

APPROVED BY THE MEMBERS OF THE THESIS COMMITTEE:

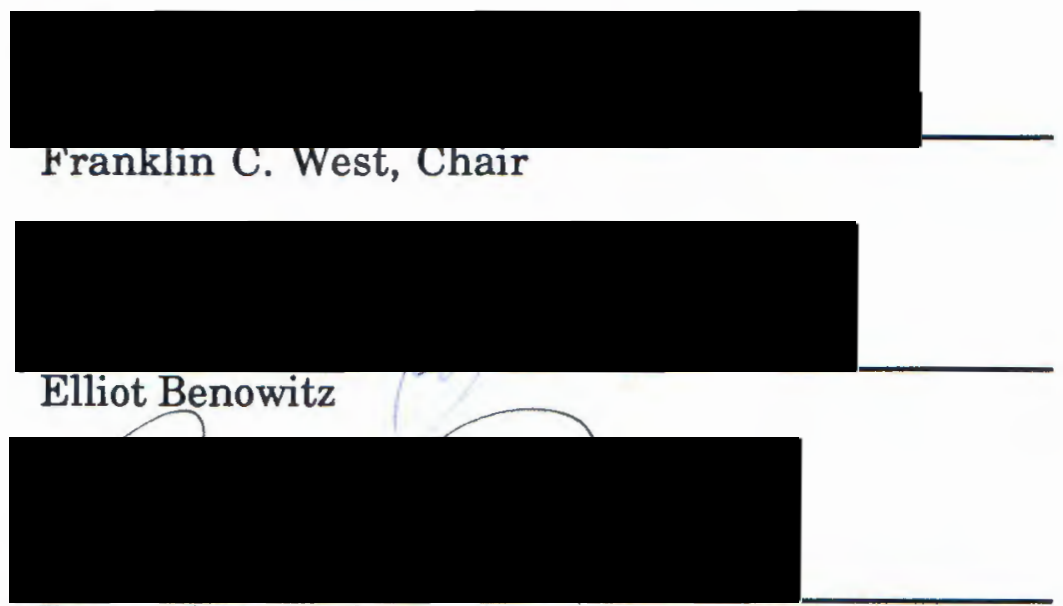

Bernard V. Burke

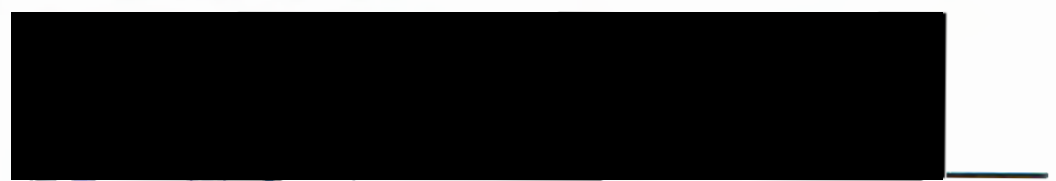

Burton W. Onstine

Historians have expressed a variety of opinions concerning the true significance of the Congress of Berlin. While the 1878 meeting did not have to deal with questions as comprehensive as those discussed in Vienna in 1814-1815 or at Paris in 1856, the Congress of Berlin had great impact in its own right. While the Berlin meeting made decisions in order to reorganize the Balkans after years of instability and war, it also created a split in 
relations between the German Empire and Imperial Russia which would eventually drive the two powers towards conflict in "The Great War" in 1914.

To understand the positions taken by the Great Powers and the decisions made at the Congress, the thesis describes the nationalist uprisings which exploded in the Balkans in 1875, when many of the Balkan peoples revolted against the oppressive rule of the Ottoman Turks. Despite the effort of the Great Powers to calm the violence, the situation deteriorated. After an unsuccessful war by Serbia and Montenegro for liberation from Turkey, the Russians decided to settle the situation themselves through war against the Turks in 1877-1878. Under the banner of Slavic unity, the Russians thoroughly defeated the Turks, and then dictated the harsh peace of San Stefano. At San Stefano, the Russians attempted to solve "The Eastern Question" unilaterally by creating a Southeastern Europe under Russian and Slavic domination.

However, statesmen elsewhere in Europe saw the Treaty of San Stefano as upsetting the balance of power in Europe. This was especially a concern for Great Britain and Austria-Hungary. For several months England prepared for war against Russia. It was in this tense atmosphere that the Congress of Berlin met in 1878.

The thesis then focuses on the Congress itself, which basically sought to reverse the unpopular Treaty of San Stefano and create a new balance of power in the Balkans. Under the leadership of German Chancellor Otto von Bismarck, the Congress eventually agreed on the Treaty of Berlin, thus avoiding a European war. This agreement created several new independent countries (including a divided Bulgaria), granted 
Austria-Hungary the right to occupy the provinces of Bosnia-Herzegovina, and settled questions concerning the Black Sea, the Danube River, and Northern Armenia. This solution allowed Europe to remain at peace for over thirty years.

However, the impact of these decisions had serious consequences on German-Russian relations, as Tsarist officials blamed Germany for allowing England and Austria-Hungary to win major concessions at the Congress. And despite a long-standing friendship, the Tsar threatened a war of retaliation against Germany. This sudden crisis helped solidify the growing close relations between Germany and Austria-Hungary, and in October 1879, a defensive alliance was signed by the two German powers. This would prove to be the first alliance in the slow build-up of tensions leading to World War I.

Thus, this thesis undertakes to show that the Congress of Berlin should rightly be considered a major watershed in European diplomatic history. Not only did the Congress produce a respectable solution for "The Eastern Question," but without intending it, also created a irreconcilable split in German-Russian relations, while encouraging Germany and Austria-Hungary to form a military alliance. These last points would be crucial in creating an atmosphere necessary for a major war in August 1914. 
THE CONGRESS OF BERLIN OF 1878:

ITS ORIGINS AND CONSEQUENCES

\author{
by \\ KENNETH ALLEN SHAFER
}

A thesis submitted in partial fulfillment of the requirements for the degree of

MASTER OF ARTS

in

HISTORY

Portland State University

1989 
TO THE OFFICE OF GRADUATE STUDIES:

The members of the Committee approve the thesis of Kenneth Allen Shafer presented June 29, 1989.

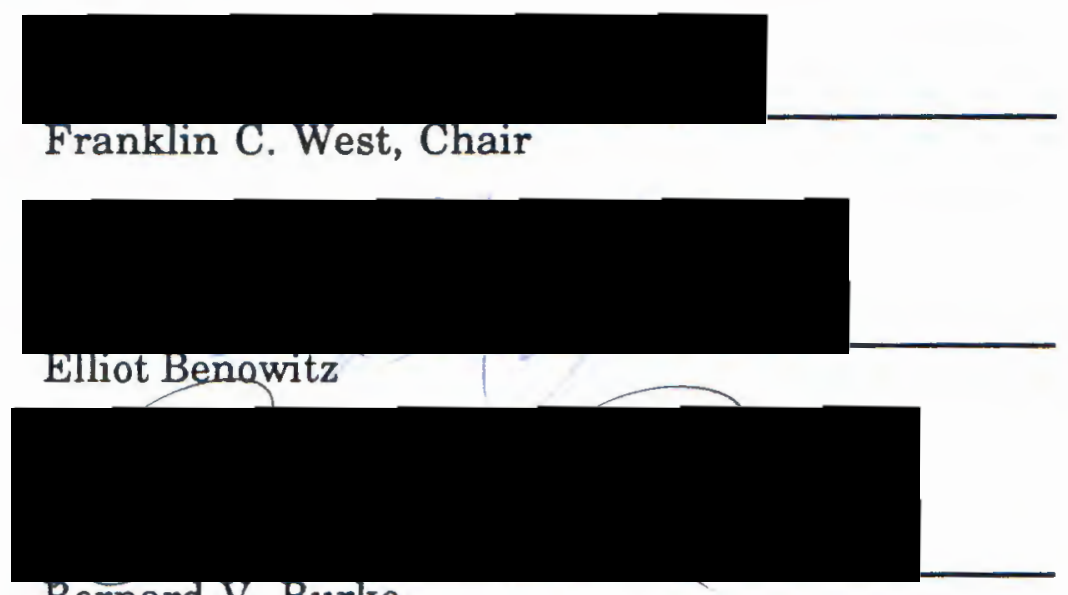

Bernard V. Burke

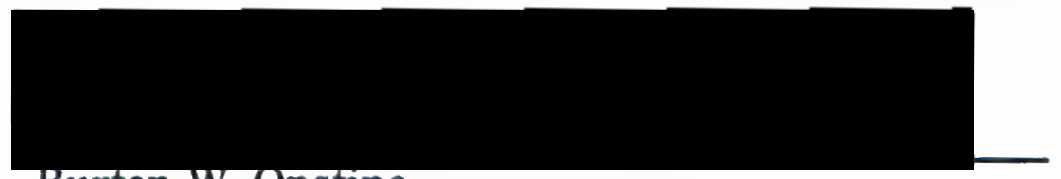

Burton W. Onstine

APPROVED:

Bernard V. Burke, Chair, Department of History

C. William Savery, Vice Provost for Graduate Szadies and Research 
TABLE OF CONTENTS

\section{PAGE}

LIST OF FIGURES $\ldots \ldots \ldots \ldots \ldots \ldots \ldots \ldots \ldots$ iv

\section{CHAPTER}

I INTRODUCTION $\ldots \ldots \ldots \ldots \ldots \ldots \ldots \ldots \ldots$

II THE SITUATION IN EUROPE, BEFORE $1875 \ldots \ldots \quad 7$

III THE BALKAN CRISIS, $1875-1878 \ldots \ldots \ldots \ldots \ldots$

IV THE RUSSO-TURKISH WAR, 1877-1878 . . . . . 36

V THE CONGRESS OF PERLIN OF $1878 \ldots \ldots \ldots . .49$

VI REACTION TO THE TREATY OF BERLIN AND THE

FORMATION OF THE DUAL ALLIANCE . . $\quad 69$

VII CONCLUSION ................. 88

REFERENCES $\ldots \ldots \ldots \ldots \ldots \ldots \ldots \ldots \ldots \ldots \ldots \ldots \ldots \ldots \ldots$ 


\section{LIST OF FIGURES}

FIGURE

PAGE

1. Map of Treaty of San Stefano, 1878 and Treaty

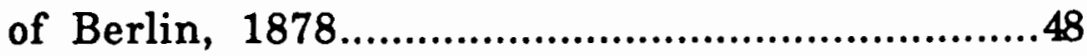




\section{CHAPTER I}

\section{INTRODUCTION}

Historians have had differing opinions on the significance of the 1878 Congress of Berlin. George E. Buckle made that clear by stating the Congress of Berlin, with its resulting treaty, is a landmark in the diplomatic history of the Nineteenth Century; but of the real value and importance of its work, there have been very varying appreciations. ${ }^{1}$

Indeed, there seems to be no real agreement on the Congress, as W. N. Medlicott wrote, "in reality, the Congress was an exercise in guesswork and make-believe for all the powers." 2 Commenting on the ensuing Treaty of Berlin, J. A. Marriott noted that "the enduring significance of the treaty is to be found...in the new nations which were arising upon the ruins of that [Ottoman] Empire." ${ }^{3}$ However, L. S. Stavrianos completely disagreed:

an essential feature of the treaty was its disregard of ethnic and nationalist considerations...For the Balkan peoples, then the Treaty of Berlin meant frustration of nationalist aspirations and future wars. ${ }^{4}$

1 George Earle Buckle, Life of Benjamin Disrael, 1876-1881, vol. 6 (New York: The MacMillan Company, 1920), 310.

2 W. N. Medlicott, The Congress of Berlin and After--A Diplomatic History of the Near Eastern Settlement. 1878-1880, 134.

3 J. A. R. Marriott, The Eastern Question--A Study in European Diplomacy, 4th ed., (London: Oxford University Press, 1947), 345.

${ }^{4}$ L. S. Stavrianos, The Balkans 1815-1914 (New York: Holt, Rinehart, Winston, 1963), 70-71. 
With such varying opinions on the 1878 Congress and on the decisions made there, then it should be a fascinating topic to study.

To recognize the importance of the Congress, consider the fact that the meeting took place in a crucial period of European history, as many changes had recently occurred on the continent. For instance, the Berlin Congress was the first major international meeting after the unification of Germany. This is imperative to keep in mind, for the defeat of France had made united Germany the most powerful country in Western Europe after 1871. The fact that the Congress was held in Berlin reflected Germany's new power, as before 1871 , such crucial meetings were held in some city such as Paris, London, or Vienna.

Some very prominent individuals who are still greatly admired and studied played major roles at Berlin, and they also signify the importance of the meeting. Foremost among those figures was the distinguished German Chancellor, Prince Otto von Bismarck. Since Bismarck acted as the president of the Berlin proceedings, and since the other delegates accepted Bismarck's solution of partitioning the Ottoman Empire in order to maintain European peace, it can be argued that the 1878 Congress represented Bismarck's height of influence and power in Europe. There were other famous individuals at that meeting, such as British Prime Minister Benjamin Disraeli, and Lord Robert Salisbury, the then British Foreign Minister and future Prime Minister. Also there was the AustroHungarian Foreign Secretary Count Julius Andrassy, a man who played a decisive role in the Congress. Meanwhile, the Russian Ambassador to London, Count Peter Shuvalov, eventually gained the most respect of the Russian delegation in the eyes of the other delegates. This is despite the 
fact that Shuvalov did not hold the highest position in the Russian commission. These individuals and others will be discussed as well in this historical study.

The decisions made at the 1878 meeting were also important. The Congress' main goal was to solve "The Eastern Question," that is, determining who would control Southeastern Europe after the Ottoman Empire lost control of their territories in the Balkans. Indeed, the Congress was successful in creating a generally peaceful situation in Southeastern Europe which lasted for over thirty years. The Congress of Berlin also represented another attempt to solve major continental problems by "Conference Diplomacy."

Conference Diplomacy dates from the beginning of the western state-system at the Congress of Westphalia [1642-1648], which ended the Thirty-Years War. It was used with increased frequency in th Eighteenth and Nineteenth Centuries. 5

These conferences were "large-scale multilateral diplomatic negotiations conducted at international meetings."6 But a "Congress" was the highest level meeting that existed in the diplomatic world, as a Congress would convene only to discuss a very specific topic, and it would include the highest-ranking representatives of all the European powers, all of whom

5 Jack S. Plano and Roy Olton, The International Relations Dictionary (New York: Holt, Rinehart, and Winston, Inc., 1969), 212.

${ }^{6}$ Tbid., 212. 
would be equal in voting power while at the Congress. ${ }^{7}$ There would be other conferences after Berlin, but never with the title of "Congress."

One nation that tried to take advantage of Germany's new power at the Congress was Russia. Traditionally, Russia and Prussia had always had close ties, and after German unification, Russia hoped to use Germany's strength to achieve some of her long-held foreign objectives. Thus, when the Congress convened in Berlin, Tsarist officials expected Germany to continue to support Russia as she always had done before. But when the decisions made at Berlin did not satisfy the Tsar, Russian officials believed that they had been deserted by Germany. Worst yet, the Tsar thought that Germany had given her full support to Russia's rival in the Balkans, the Austro-Hungarian Empire. The Tsar never fully forgave Germany for her actions in 1878, and so after the Berlin Congress, Russian-German relations were never quite the same again.

Thus, in looking for a root cause for war in 1914 between Germany, Austria-Hungary and Russia, then one must seriously consider the Congress of Berlin of 1878 , as this was the turning point where relations between these three nations noticeably started to deteriorate. As before 1878, these three powers had made up the Three Emperors' League (Der Dreikaiserbund), an association started in 1873 (and renewed in 1881) of friendship, ideology, and cooperation. Although the three states were never formally allied, there were many long-standing links between them.

7 This type of Congress should not be confused with the 'Congress System' "instituted by Article VI of the Quadruple Alliance of Britain, Austria, Prussia and Russia, signed in Paris in 1815." For soon, England withdrew from this system, and then it finally collapsed by 1825 . A. W. Palmer, A Dictionary of Modern History 1789-1945 (London: The Cresset Press, 1962), 68. 
Although no doubt many differences existed within the Dreikaiserbund, none of them was so serious that negotiations could not solve them. But when Russia perceived, rightly or wrongly, that it was Germany which blocked the achievement of their goals at the Congress in 1878, then the Tsar spoke openly for the first time of attacking his western neighbors in retaliation.

While the 1878 meeting started the degeneration in relations between Russia and Germany, the Berlin Congress also represented the corresponding solidification of relations between Germany and AustriaHungary. For these two nations signed a defensive military alliance in 1879, soon after the Tsar had made his war threats known. This close friendship between the two German powers lasted until 1918.

Thus, the purpose of this historical investigation is to portray the 1878 Congress of Berlin as a particularly significant event in European diplomacy, not only because of the decisions that it took towards solving the "Eastern Question," but also as a root cause of later Russo-German antagonism (which eventually erupted in 1914) and the Austro-German alliance of 1879 .

But in order to study the Congress of Berlin fully, the situation in Europe leading up to the Congress must be presented and understood. This means analyzing the crucial shifts in Europe after 1871, as well as the uprisings in the Balkans starting in 1875. The resulting Russo-Turkish War of 1877-1878 will also then be reviewed, for it was the reaction to the outcome of this war that forced the Congress to be called.

The focus of this investigation will then shift to the meeting itself in 1878 , the powers and individuals of the Congress, and the decisions made. 
Finally, the consequences of the Congress as well as the reactions to the meeting will be examined, including the signing of the Dual Alliance. Thus, this thesis aims to inform the reader in detail of the events concerning the Congress of Berlin of 1878 , as well as the ramifications associated with it. 


\section{CHAPTER II}

\section{THE SITUATION IN EUROPE, BEFORE 1875}

In order to understand the Congress of Berlin fully, it is necessary to consider the positions of the powers that participated in the meeting. This is especially important because many aims and policies of the Great Powers had shifted in the years prior to the 1878 Congress, mainly because of the significant changes to the European continent.

For a period after the Congress of Vienna in 1814-1815, Europe for the most part remained relatively unchanged, since the major powers at that meeting had agreed to create a balance of power and to work together to maintain that system as much as possible. For a generation, this arrangement worked, as it was mutually beneficial for all the Great Powers. That long-standing order was seriously tested for the first time by Imperial Russia, when they attempted expansion into the Ottoman Empire during the Crimean War of 1853-1856. It was mainly the cooperation of Great Britain and France which managed to stop the Russian quest to dominate the Balkan region. For it was the main task of the European Concert created at Vienna to stop any attempt by a single power or a coalition to gain a commanding position on the continent. The 1856 Treaty of Paris, which ended the Crimean War, recreated a balance in the Balkans, strengthened the position of the Ottoman Empire in Europe once again, and greatly weakened Imperial Russia's ability to attempt a similar attack later. In the 1856 treaty, Russia was "forbidden to maintain naval 
forces in the Black Sea or to build...arsenals on its shores...[and] Russia was required to cede to Moldavia three districts of Southern Bessarabia."8

However, the Treaty of Paris did not create the long-lasting peace that the powers thought it would. Rather, "the Crimean War left Europe in an anarchical situation in which more powers were interested in revising what was left of the balance than were interested in preserving it." 9 As for the defeated nation, after 1856, Russia "neglected everything in Europe for the sake of her national interests. Or rather, for the sake of her national honor."10 This meant that Russia would do all that it could to destroy the humiliating Treaty of Paris.

In order to do this, Russia first launched necessary large-scale reforms in society and government, and she also rebuilt her army. To carry this out, she more or less isolated herself from European affairs to make these improvements. While in this isolation, they allowed changes to be made on the European map. The Tsarist government did not forget that their long-time ideological friend, Austria, had not come to their aid in the Crimean War and, in fact, even forced the Tsar to sue for peace. With this in mind, Russia thought Austria deserved punishment. The first sign of this came with the unification of the Italian peninsula in the 1860's, in

8 Barbara Jelavich, The Qttoman Empire, The Great Powers, and the Straits Questions, 1870-1887 (Bloomington, Indiana: Indiana University Press), 20.

9 Gordon A. Craig and Alexander L. George, Force and StatecraftDiplomatic Problems of Qur Time (New York: Oxford University Press, 1983), 36.

${ }^{10}$ A. J. P. Taylor, The Struggle For Mastery in Europe, 1848-1918 (Oxford, England: Oxford Clarendon Press, 1954), 90-91. 
which Italy gained lands from Austria by diplomacy and war. The Russians manifested their anger a second time when they did not interfere with Prussia's defeat of Austria in 1866. Thus, the decision not to help the Russians in Crimea had come back to haunt the Austrians.

Austria was not the only power which provoked the Russian desire for revenge. Tsar Alexander II also despised France for its role in the Crimea, and when Prussia defeated France in a stunning fashion in 18701871, Russia did nothing to prevent it. With the Prussian victory over France, the long-awaited unification of Germany was completed. The Tsar thought he could use the new Germany as a way to obtain some of his foreign policy objectives. But it was not long after German unification that the Tsar realized that the new Germany was more powerful--and threatening--than he had anticipated. This was especially a concern for Russian Foreign Secretary Alexander Gorchakov, who did not trust Bismarck.

The unification of Germany into a single nation-state had profound impacts in the European balance of power, a change that would last until 1918 and beyond. The rapid German military victory over France had proven beyond the doubt that the dominance of the French army had ended. With the military victory, Germany (which now also included the annexed French provinces of Alsace-Lorraine) became the most powerful nation in Europe west of Russia. But with these developments for Germany also came responsibility, as she was forced to assume France's role as the center of European diplomacy, whether they wanted it or not. That would be a great burden for the new state, but luckily, German policy was guided by the brilliant Chancellor, Prince Otto von Bismarck, who was well- 
qualified to master such a position as that of the continent's leading diplomat. Yet even he would soon find that such a position had many potential problems.

After the French defeat by Prussia, their Emperor Napoleon III abdicated, and the Third Republic was proclaimed. This change fit in perfectly with Bismarck's designs. For as long as Germany held the two French provinces (Alsace-Lorraine), Bismarck feared for a French nationalist drive to retake the regions. However, in Bismarck's eyes, such an attempt was far less likely under a democratically-elected government than under a possibly ambitious and nationalistic monarchy. Thus,

Bismarck openly expressed his wish that France should choose not restoration [of the monarchy], but remain a republic. This form of government...in Bismarck's view, best calculated to perpetuate French isolation and weakness. 11

A constant effort to keep France isolated from the rest of Europe became the basis--and perhaps obsession--of Bismarck's foreign policy.12

However, France's isolation after 1871 was not all of Bismarck's work. The real and symbolic loss in power and status lost them many friends and admirers. "What France had lost was not so much two provinces, as the primacy of Europe...the lost provinces were a symbol of lost greatness."13 To remedy this problem of isolation, France decided to

11 W. R. Fryer and B. Litt, "The Republic and the Iron Chancellor: The Pattern of French-German Relations, 1841-1890," Royal Historical Transactions 29 (1979): 177.

12 Bismarck agreed with Russian Ambassador Pete Shuvalov, that he had constant nightmares about a possible hostile coalition against Germany: Otto Fürst von Bismarck, Gedanken und Errinnerungen Zweiter Band (Stuttgart, J. G. Cottásche Buchlandlung, 1915), 269.

13 Fryer and Litt, 171. 
temporarily accept the new situation and not involve themselves in serious international disputes. In this manner, France chose to allow the Three Northern Powers to deal with the Eastern Question alone, hoping that the members of the Dreikaiserbund would fight among themselves over their conflicting ideas in Southeastern Europe. If this had happened, then France envisioned that the Three Emperors' League might well have collapsed over these disagreements.

Austria, too, had long played an important role in European diplomacy, and in maintaining the Concert of Europe. ${ }^{14}$ But the Austrian defeat by Prussia meant that its dominating position in Germany had finally come to a close with the Treaty of Prague in 1866. However, a hope of revenge was held by many Austrians who had been active in the government for a long time.

The collapse of the German settlement of the Treaty of Prague was in no sense a foregone conclusion. [Austrian Foreign Minister Count Frederick] Beust's German policy for involving Austria-Hungary was by no means a proven failure. ${ }^{15}$

But any real chance of that vanished with the 1871 French defeat. "Austria was cooperative with France and hostile to Germany until Sedan, and then after Sedan, she became hostile toward France and cooperative with

14 The Austrian belief in maintaining the conservative order and balance of power had dominated their foreign policy since the Congress of Vienna of 1815. Winfried Baumgart, Vom Europäischen Konzert zum Völkerbund (Darmstadt: Wissenschaftliche Buchgesellschaft, 1974), 4-5.

15 F. R. Bridge, From Sadowa to Sarajevo-The Foreign Policy of Austria-Hungary, 1866-1914 (London: Routledge and Kegan Paul, 1972), 44. 
Germany." 16 To fully indicate that a new policy towards Germany was being implemented in 1871 , Beust, "who was evidently not the man to inspire confidence at Berlin, was dismissed, and...Count Julius Andrassy became minister of foreign affairs."17 For Beust had "plans for a South German Confederation to bind the southern states together against Prussia." 18 But Andrassy had no desire of reasserting Austria's role in German affairs. Rather, as a Hungarian, he was much more concerned about possible threats from the eastern neighbor, Russia. Furthermore, Andrassy wanted to block any attempt to create a large Slavic state to the south of Austria.

The Magyars felt themselves stranded in the great Slavic sea of Eastern Europe, and saw their only hope in the alliance with Germany...His [Andrassy's] object, therefore, was to draw the Germans away from the Russians, and attach them to the Austrian side. ${ }^{19}$

In fact, Andrassy once said, "Austria's mission remains...to be a bulwark against Russia, and only so long as she fulfills this mission is her existence a necessity for Europe."20

16 Brian Healy and Arthur Stein, "The Balance of Power in International History-Theory and Reality," Journal of Conflict Resolution 17 , no. 1 (1973): 41.

17 William L. Langer, European Alliances and Alignments, 18711890 (New York: Alfred A. Knopf, Inc., 1956), 19-20. Count Beust, who came to the foreign ministry in 1866, still harbored revenge dreams against Prussia. During the Franco-Prussian War, he gave serious consideration into intervening for the French, but the war was decided too quickly. Thus, in order to build close relations with Berlin, Beust had to go.

18 Bridge, 44.

19 Langer, 20.

20 Bridge, 50. 
Andrassy's advancement to the position of foreign minister also represented another major change in Austria since their 1866 defeat. This major setback, while not bringing down the government as in France in 1870 , had forced a lasting change in the structure of the Habsburg Monarchy. The defeat encouraged the different nationalities of the monarchy to demand more power and rights, especially the Hungarians, as they constituted the largest and most organized non-German populace in the empire. The outcome of this campaign was the creation of the "Ausgleich" (settlement) of 1867. This meant that

...the Habsburg Empire remained under a single ruler, who presided over a newly formed Dual Monarchy as emperor of Austria and king of Hungary. The emperor was still the supreme authority.... The unity of the empire was maintained in the three crucial fields of foreign policy, war and finance.... In all other respects, the two parts of the empire were separate. ${ }^{21}$

Thus, "the Ausgleich was to mark the permanent defeat of the Germanizers in the empire, which from now on, had to be governed to a far greater extent...through the non-German elements." 22 What this meant was, that while the Germans in Austria often wanted to pursue one policy, the Hungarians would use their new powers to object. In these situations, it was usually the Hungarians who got their wish, as they were more successful at using their voice in matters of foreign policy. In fact, the

21 Norman Rich, The Age of Nationalism and Reform, 1850-1890, 2d ed., (New York: W. W. Norton and Company, 1970), 205. The Ausgleich also spelled out constitutional reforms, and gave jurisdiction of certain areas of the empire to either Austrian or Hungarian authorities, including areas inhabited mainly by Slavs. For more on Ausgleich, see Rich, 202-216.

22 Ibid., 205. 
Hungarian voice in foreign policy would usually dominate Austro-

Hungarian thinking until 1918.

As for Russia, her decision to allow German unification had immediate results. "Russia had used the occasion of the French-Prussian War to secure the abrogation of the Black Sea clauses of the Treaty of Paris."23 Thus, the Tsar was successful in destroying part of that hated peace treaty. But this was just the first step, as the Russians had bigger goals in mind. "Russia often changed her policy...but her purpose was ever constant and clear--to acquire herself the control over the Straits."24 But while the internal reforms at home were making progress, the Tsar had to be mindful of the ever-growing revolutionary and radical elements within Imperial Russia. Many of the Tsar's foreign policy decisions were geared towards showing the glory and power of Russia, and to make Russians more patriotic and proud of the Romanov crown. In this manner, the Tsar hoped to lessen the danger of a revolution.

Great Britain was also changing policies. After many blunders during the Crimean War, the English assumed the strategy of "Splendid Isolation," which meant that they would not involve themselves in another foreign war unless the fabric of the empire was threatened. ${ }^{25}$ Instead, it

23 Barbara Jelavich, A Century of Russian Foreign Policy, 1814-1914 (Philadelphia: J. B. Lippincott Company, 1964), 160-161. In the Black Sea Clauses, Russia was forbidden to maintain warships or arsenals on the sea. Also, the Straits were closed to all warships, but open to all merchant ships. For more, see Jelavich, 129-130.

24 Baron S. A. Korff, Russia's Foreign Relations During The Last Half Century (New York: The MacMillan Company, 1922), 114.

25 George Earle Buckle, The Life of Benjamin Disraeli, 1876-1881, vol. 4, (New York: The MacMillan Company, 1920). Later, during the 1877 Russo-Turkish War, Disraeli described his country's policy as "one of 
focused attention on domestic and social reforms. With a new powerful Germany acting as a mediator on the continent, British isolation was assured. This attitude continued throughout the 1878 Congress.

Finally, the Ottoman Empire must be considered, not because of its strength, but because of its continual disintegration. The problems of nationality, religion, and corruption in the old empire were vast. Though the empire had formally been accepted as a Great Power in the Treaty of Paris of 1856, all the parties knew that the Sultan depended largely on Great Britain and Austria for support and protection. The 1856 treaty required the Sultan to undertake many reforms to strengthen his shaky regime. Most of these reforms were never implemented, and the situation only worsened. The likely collapse of the Ottoman Empire opened up questions concerning who would replace the Turks in the Balkans. This was the crux of the perpetual "Eastern Question."

This so-called Eastern Question...was the single major theme in Great Power diplomacy in this period. The control of the Ottoman possessions and the central government was constantly the object of discussion, negotiation, controversy, and open warfare between the major powers. 26

However, with the growing reports of Turkish atrocities and the refusal to reform, English interests in maintaining the Turkish Empire were not quite as vital as they once had been. This was especially the case because the British had gained "controlling share of the stock of the Suez Canal Company by the purchase of the shares of the impecunious Khedive of

conditional neutrality--neutrality, that is so long as British interests were not assailed or menaced....", 192.

26 Jelavich, The Ottoman Empire..., 3. 
Egypt, in November 1875."27 And since the canal gave England a direct route to India, this meant that the importance of maintaining the Sultan's hold of the Straits and Constantinople was not as vital as it had been. Why depend on the weakening Ottoman Empire when England had control of her own path to India? This shift in policy towards maintaining the status of Egypt instead of Constantinople also reflected the differences of opinion between the British political parties over the course of domestic and foreign policy. The causes of Liberalism were dominating English politics at this time, and since these ideals stressed social reforms and equality, the last thing that many people in Britain wanted was to be associated with the reactionary and backward Ottoman Turks. The Turks discovered this change in policy and attitudes increasingly as "the value of British support depended on the readiness and willingness of that power to maintain its...role in the east." 28 Even Austria-Hungary was losing interest in maintaining the Sultan's empire. ${ }^{29}$ Habsburg officials realized that only the Balkans offered an area of expansion after 1871. Furthermore, if the Slavic peoples in the Ottoman Empire continued to be a destabilizing factor, the Dual Monarchy could not allow such serious unrest on its borders. As a result, the Turks found themselves increasingly isolated, which made

\section{Langer, 73.}

28 Jelavich, The Ottoman Empire..., 6-7. This crucial change in British foreign policy towards the Turks will be important to keep in mind, as this was a factor that played a key role up through 1878.

29 "Andrassy's standpoint throughout was...that the Ottoman Empire should be maintained as long as possible...[but if] the Ottoman Empire went to pieces...he would have regarded annexation as a necessary precaution." Langer, 70-71. 
"The Eastern Question" even more of an important element in European politics. When the Sultan had little or no outside support, then his control over Southeastern Europe became still more uncertain and weak.

But while much of the attention was focused on the activities of the Great Powers at this time, the growing forces of nationalism in the Balkans could not be ignored. Particularly since the Crimean War, the various peoples of the Balkans were increasingly demanding their independence or at least autonomy from the Ottoman Turks. This was especially prevalent in Rumania, Serbia, and Montenegro. After 1856, these regions had received a great deal of autonomy, but this did not seem to fully satisfy the people. The Serbians, for example, represented the largest Slavic population in the Balkans, and they continued to dream not only of independence, but also they saw themselves as leading the way to the creation of a great united Slavic state. But nationalism was not just limited to these peoples. Despite the best efforts of Turkish authorities to stop the ideals of nationalism from spreading, other peoples soon learned of it also. A small Greek state had been formed in the 1830's and had been growing since; and the Greeks looked to unite all the Greeks into one nation. Even the isolated Bulgarians, as we shall soon see, were increasingly interested in the ideals of nationalism.

What was so dangerous about this growing nationalism in the Balkans was the fact that each nationality had their own brand of nationalism and goals. This meant that these goals often were conflicting, and they could not be fully controlled by any of the Great Powers. Although the Russians thought they could direct most of the Balkan peoples by the dreams of Pan-Slavism, "the other Slav nations shunned the friendship of 
Russia. Russian friendship or assistance meant much more domination than federation."30 Another writer commented "the second half of the Nineteenth Century witnessed the death of Slavism and the birth of a great variety of regional nationalisms." 31 Despite this fact, the Russian PanSlavs continued to believe otherwise. But the power most concerned with the rise of nationalism among the Slavs was Austria-Hungary. Habsburg officials were always concerned that a great uprising or a war for Slavic unity might capture the hearts of the Slavs within the Dual Monarchy, and so Austrian officials always had to work hard to prevent this possibility from happening.

Thus, with a knowledge of the positions of the situation in Europe before the Congress of Berlin, we can better understand the policies followed at the meeting. However, before we discuss the Congress, it is important to follow the course of events that actually brought about the meeting, namely the uprisings in the Balkans which started in 1875, and the subsequent Russo-Turkish War of 1877-1878.

30 Korff, 117.

31 Peter F. Sugar, "The Southern Slav Image of Russia in the Nineteenth Century," Journal of Central European Affairs 21, no. 1 (April 1961): 48. 


\section{CHAPTER III}

\section{THE BALKAN CRISIS, 1875-1878}

When the Treaty of Paris was signed in 1856 ending the Crimean War, the Great Powers thought that they had solved the problems of Turkish-controlled Southeastern Europe by imposing required reforms on the Sultan. But despite all the promises and fanfare given these reforms in 1856, most were never implemented. For several years after 1856, the situation in the Balkans appeared fairly calm, but in reality, it was like a powder keg ready to explode. Finally, the fuse went off in the summer of 1875 "when the Turkish authorities began to exact by force the excessive taxes which the Christians refused to pay. At the beginning of July, they revolted in Herzegovina, and a few weeks later, Bosnia was also set aflame."32 In addition, "the Sultan's reforms merely contributed to a rising anger among Moslem Turks against all types of foreign interference." 33 Thus, two completely opposite groups stubbornly faced one another in the Balkans--either it was Turk versus minority or the Turk versus the foreign powers who demanded action towards solving the many problems in the Balkans. As one author mentions, "the revolts and the

32 Mihailo D. Stojanovic, The Great Powers and the Balkans (Cambridge, England: Cambridge University Press, 1939), 15.

${ }^{33}$ G. D. Clayton, Britain and the Eastern Question--Missolonghi to Gallipoli (Londong: University of London Press, Ltd., 1971), 122. 
Eastern Crisis had world-wide consequences for the history of all the Balkan peoples." 34

The initial aim [of the revolt] seems to have been an improvement in the quality of Turkish rule, rather than independence...[but] whether the rebels wished it or not, their cause was certain to be taken up by the outside interested parties. ${ }^{35}$

The fact that outside powers became involved was a key element, as especially Russia and Austria-Hungary had their own goals and concerns in the Balkans. In fact, the Balkan Crisis presented a perfect opportunity for Russia, because Alexander II's policy towards the Ottoman Empire since the Crimean War had changed from forcing its dismemberment to that of overseeing its natural decay. ${ }^{36}$

However, for the Habsburg Monarchy, reports of the Balkan uprisings were anything but good news. It had been a long-held policy of Austria to maintain the status quo of the Ottoman Empire, mostly because it was home to many Slavic peoples. For Foreign Minister Andrassy, "partition of Turkey in Europe was almost as abhorrent to him as its domination by Russia."37 Since the Dual Monarchy also contained many Slavs, the fear was that a nationalist uprising by the Slavs in the neighboring Ottoman Empire could spread across the border. Given the extent of the unrest existing in the Balkans, this danger seemed very real.

${ }^{34}$ Arnold Suppan, "Bösnischer Aufstand und Orientkrise, 18751878," Österreichische Osthefte 18, no. 2 (1976): 189.

35 Clayton, 130.

36 Baumgart, 37.

37 Taylor, 248. 
Therefore, Austrian Foreign Minister Andrassy's "great objective was that all symptoms of solidarity between the insurgents and the South Slavs in the Dual Monarchy must at any cost be avoided."38 The total contrast between Russian strategy and Austrian policy was very clear, and with this divergence came obvious competition and high tensions.

In the early period of the uprisings, both Turkish authorities and the Great Powers kept the activities from spreading outside the Ottoman Empire or causing a general Balkans War, but the riots which concerned Austria-Hungary most closely still continued. Bosnia-Herzegovina laid directly on the border of the Dual Monarchy, and many of the refugees fled into Austrian territory, creating high tensions. For not only were many people fleeing into the Dual Monarchy, causing hardships and shortages, but also revolutionaries came with the refugees. Hence, Austria became an unwilling haven for radicals, revolutionary newspapers, and a place to store weapons to secretly ship into the rebellious regions. With this going on, Andrassy acted first, by writing to the Sultan "The Andrassy Note" on January 30,1876 . The note demanded four reforms without delay: a) the establishment of full religious liberty and equality, b) the abolition of taxfarming, c) the application of the revenues gathered in Bosnia and Herzegovina entirely to local purposes, and d) the amelioration of the agricultural population. ${ }^{39}$ These required improvements Andrassy

38 George Hoover Rupp, A Wavering Friendship--Russia and Austria, 1876-1878 (Cambridge, Massachusetts: Harvard University Press, 1941), 84 .

39 Stephen Pierce Hayden Duggan, The Eastern Question--A Study in Diplomacy (New York: AMS Press, 1970), Reprint 1902, 130-131. Andrassy's note contained more specifics for each of these provisions, thus, turn to this text for more details. 
wanted included augmenting the basic standard of living and modernizing rural life. Though this message solved some of the problems of taxation, government, and religion, Andrassy failed to offer any solutions for the main issue of nationalism. But this was not surprising, for the Dual Monarchy had historically discriminated against the Slavs within her own borders. If Andrassy demanded that wholesale changes be made to appease the Slavs within the Ottoman Empire, then Austria's own Slavic population might well demand similar rights. Thus, because "The Andrassy Note" did not offer any worthwhile or realistic solutions, it received a very cool response, mostly because the desire for national selfdetermination was the main issue for those who lived in the Balkans, whereas the issues of taxation and religion were only secondary. Furthermore, the other Great Powers did not have much respect for Austria-Hungary's attempt to solve the Balkan uprisings without the participation of the other powers. Thus, "The Andrassy Note" was doomed to failure in the minds of both the Great Powers and the Balkan nationals. "The Andrassy Note" turned out to be just the first in a series of attempts by the powers to resolve the Balkan uprisings by diplomatic means, rather than allowing the problem to become more serious. However, Andrassy's unilateral action particularly disturbed Russia, since she rightly considered herself entitled to play a vital part in any Balkan political solution. Moreover, the Austrian note was a violation of the Three Emperors' League ideal of acting in accordance with the other Northern Powers on matters in the Balkans. Accordingly, Andrassy urged another diplomatic move, which brought the Russian Chancellor, Prince Alexander Gorchakov, to Berlin for a meeting. These talks produced "The 
Berlin Memorandum" on May 13, 1876. "This document merely urged the Turks to grant an armistice to the rebels and to institute reforms on the lines of the Andrassy Note." 40 More importantly however, "Russia consented to Austria's taking a portion of Bosnia [in case of an impending Balkans War] and reserved Bessarabia for herself.... It was the first success of the Bismarckian policy of partition."41 Thus, this was also the first sign of the eventual agreement later made in 1878, that would grant Austria-Hungary the right to occupy the Turkish provinces of BosniaHerzegovina, while Russia reacquired Bessarabia.

The Berlin Memorandum also signified some other important points. The constant unrest in the Balkans showed the Austrians that the disintegration of the Ottoman Empire was unavoidable, and since the Turks could not handle the rebellion, perhaps this was a sign that the disintegration of the empire might come sooner than expected, or worse yet, turn into a sudden collapse. To prepare for such an eventuality, Andrassy "could not avoid a policy which prepared the way for the acquisition of the two Turkish provinces [of Bosnia and Herzegovina]."42 It seems that Andrassy was the one most resistant to admit this, as annexing the two provinces would only bring in more Slavs under Habsburg rule. Since Andrassy was a Hungarian, he did not wish to see that happen, as such an acquisition threatened the political position the Hungarians achieved in 1867 in the Ausgleich. In the Dualist system arranged by the Ausgleich,

40 Bridge, 76.

41 Stojanovic, 62.

42 Rupp, 35. 
the Hungarians held at least an equal voice in the policies of the Habsburg Monarchy. But there were already many Slavs in the monarchy who wished the empire to become a triple monarchy, so "Andrassy was fundamentally opposed to the inclusion of more Slavs in the Dual Monarchy, in which the nice balance of German and Magyar was already threatened." 43 If Bosnia-Herzegovina was annexed by the monarchy, then that might have given the added pressure needed to force the Habsburg government to assume a triple monarchy structure. Andrassy wanted to protect the special powers that the Hungarians had finally achieved in the Ausgleich, and that position would be lost in a triple monarchy. But many other parties had been advocating the annexation of the two provinces for military and economic reasons. However, the most convincing argument for Andrassy was the fear that if Austria-Hungary did not get them, then the areas might be seized by a large Slavic state, possibly a Russian satellite. Thus, Andrassy finally succumbed to this realization, and, "incorporating Bosnia and Herzegovina came as definite goal, and it became the dominant active feature of Austrian foreign policy from 1875 on down to 1914."44

The memorandum also symbolized an agreement on a "policy pursued by Russia and Austria for over a century past...[that was] a division of the [Balkan] Peninsula into an eastern and a western sphere of influence." 45 This is in fact exactly what Bismarck wanted to do anyway,

43 Ibid., 35.

44 Ibid., 25.

45 R. W. Seton-Watson, "Russian Commitments in the Bosnian Question and an Early Project of Annexation," The Slavonic and East European Review 8 (1929/1930): 580. 
England should agree for each of them to occupy in the east--at Turkey's expense--a position satisfying them for the time being and preventing them from turning against each other." 46 Hence, the two Northern Powers had adopted Bismarck's plan of partition without realizing it, but they did it only because it fulfilled both of their vital interests.

However, when the Berlin Memorandum was submitted abroad for approval, it received a very stern reply from the British. London

rejected joint diplomatic action by the powers as the means to settle the Balkan Crisis. She was bent on preserving complete freedom of maneuver and was determined to prove that the Three Emperors' League could not settle all problems by its own exclusive authority. 47

In many respects, England's refusal was based not so much on the content of the memorandum, but rather, on how the authors submitted the note to London, that is, expecting a favorable answer without prior consultation. But the answer to the plan was to pursue another strategy. Prime Minister Disraeli was determined to "recover the role of arbiter, by smashing the Three Emperors' League."48 Since Germany's unification in 1871, and especially since the creation of the Dreikaiserbund in 1873, Bismarck and

46 Count Julius Andrassy, Bismarck Andrassy and Their Successors (Boston: Houghton Mifflin Company, 1927), 25. It should be noted that this book was written by the son of the Austrian Foreign Minister, Andrassy, from 1871-1879.

47 Clayton, 134-135.

48 Ibid., 127. 
the League had taken the initiative in solving the problems of Southeastern Europe. Yet, Disraeli knew that Russian and Austrian goals clashed in that region, and if the problems persisted, then the League would collapse due to a lack of agreement. Disraeli was committed to breaking the Dreikaiserbund throughout the Congress of Berlin and, as we will see, he was successful in carrying it out. Notice that Disraeli's strategy was very similar to the one pursued by France, as explained earlier.

Thus, instead of submitting to the Berlin Memorandum, Disraeli proposed a conference of the Great Powers, but neither Russia nor Austria were interested in such a meeting, because both powers believed that they could get much more out of the war than through diplomacy. In the meantime, tensions continued to increase in the Balkans, especially between the small states of Serbia and Montenegro and the Ottoman Empire, as these two Balkan states also supported the insurrection elsewhere in the region. The impending Balkans War seemed imminent. On June 10, 1876,
A treaty of alliance and a military convention were signed [between Serbia and Montenegro], which provided for the cooperation of the two states in both the diplomatic and military fields for the purpose of liberating the Balkan Christians, and especially the Serbs, from the Turkish yoke. ${ }^{49}$

And finally, despite the attempts of some of the powers (mainly England) to stop a Balkans War, hostilities erupted on June 30, 1876. Both the Serbs and Montenegrens hopes this war of liberation would spread throughout the Balkans and liberate all the Slavs.

49 Stojanovic, 84. 
Such a hope was not a monopoly of the Balkans states; it was also harbored by many in Russia. Here, "the declaration of war...was part and parcel of the grand plan of the Pan-Slav committees for a general Balkans rising, and was essentially the beginning of war unofficially by Russia on the Ottoman Empire." 50 But even those of Pan-Slavic sentiment knew that "Serbia was not expected to defeat the Turks, but only to sustain the struggle for two months. Within that time, Russia would be prepared to enter the war herself." 51 For most Russians, Serbia represented the best hope for a Slavic victory, since they constituted the largest Slavic group in Southeastern Europe.

In the meantime, both Russia and Austria-Hungary saw this war as an opportunity to gain something for nothing. This was especially true for Russia, but if the situation looked promising enough, the Tsar intended to intervene in the war to make even bigger gains. The Dual Monarchy had a different view. If the Balkan alliance succeeded in their war with the Sultan, they might gain so much land and confidence that they would decide to turn on Austria-Hungary itself in order to liberate the Slavs there as well. But at the same time, the war presented the opportunity to gain further Russian approval for Austria to occupy the provinces of BosniaHerzegovina, and, thus, gain the provinces with no effort.

With this in mind, Austrian Foreign Minister Andrassy and Russian Foreign Minister Gorchakov met again in July 1876, and this time they signed the Reichstadt Agreement. In this treaty, "the two emperors
50 Rupp, 124.
51 Stojanovic, 85. 
had agreed on complete non-interference in the Serb war on Turkey."52 Furthermore, "although there was subsequent disagreement about the arrangements concerning Bosnia and Herzegovina, Russia was clearly allowed to resume her frontiers of $1856 . " 53$ Moreover, in the event of a Slavic victory, Serbia and Montenegro were to gain small areas in Bosnia and Herzegovina, while the remainder of the provinces were to go to the Habsburg Monarchy. Also, "Bulgaria, Roumelia, and Albania 'may' become autonomous states, and Constantinople a free city, while Thessaly and Crete fell to Greece." 54

However, such an ambitious plan never came about, as the Balkan states were soundly defeated. Only when the Sultan threatened the annihilation of Serbia and Montenegro in October 1876, did the Tsar demand that an armistice be granted by Turkey, and threatened that if she did not bring the war to an end, Russia would declare war. Thus, "the defeat of Serbia endangered her [Turkey's] position, and [this] forced her to accept the mediation of the powers," which were scheduled to meet in Constantinople in December 1876.55

The Serbo-Turkish War of 1876 had another significant result, aside from the fact that the Balkan states lost it.

52 Rupp, 127.

53 Barbara Jelavich, "Russia and the Reacquisition of Southern Bessarabia," Suidostforschungen 28 (1969): 203. This meant that Russia was given the right by Austria-Hungary to reacquire Southern Bessarabia and unspecified lands in Northern Asia Minor.

54 Seton-Watson, "Russian Commitments...," 581.

55 Stojanovic, 89. 
The main effect of Serbia's defeat was that Pan-Slav and Russian popular sympathy was now centered almost exclusively on Bulgaria; the Russians were far more prepared now to abandon Serbia and certainly Bosnia and Herzegovina to Vienna. ${ }^{56}$

This is because the Pan-Slavs had long-supported Serbian efforts in order to achieve their objectives, but the Serbs were never able to be victorious. Once more, Austria-Hungary could make sure that they did not succeed in creating a great Slavic state. Since this was the case, then, the Bulgarians appeared to actually be the best choice, because of the size of their population, and geographically, they were closer to Russia and further from possible Austrian interference. Also, Bulgaria would have brought Russia much closer to controlling the crucial Straits to the Black Sea.

During this war, while trying to quell other nationalist uprisings in the South Balkans, Turkish armies became very brutal, and committed what became known as 'The Bulgarian Atrocities.' "Just how many people lost their lives during these horrible conflicts has never been known," but there was definitely a great number of casualties and injuries, as well as property damage. ${ }^{57}$ The uncertain reports on these numbers was partly due to the conflicting accounts of journalists who often exaggerated, but "an official Turkish estimate set the casualties at 3,100 Christians and 400 Muslims. An American investigator estimated the dead at 15,000, while Bulgarian historians have claimed losses of 30,000 to 60,000 ."58 The news of the atrocities spread like wildfire through the newspapers of the world, and

56 Clayton, 136.

57 Clayton, 85.

58 Stavrinos, 63. 
especially in England, where social reforms were the popular subject of the day. Yet, this outrage was only the worst of a series of humanitarian crimes. "The news of the Bulgarian atrocities, then, came just at a time when many people in England had already lost all sympathy with the Turks and their government."59 Many people in all aspects of British society started questioning the wisdom of supporting a regime such as the Sultan's. The major voice in opposing British support of the Turks came from William Gladstone, the former prime minister and head of the Liberal Party. He spoke out many times about the atrocities in parliament almost immediately after the offenses became known. He also wrote extensively on the subject, including a short book, entitled Bulgarian Horrors.

Gladstone's bitter attacks had profound effects on Disraeli's popularity and power in England. Consequently, England went to the Constantinople Conference in an awkward position, as the other powers, especially Russia, were aware of the outcry that came about in Britain because of the Bulgarian Atrocities.

It was only natural that the Russians should deduce from this vigorous anti-Turk movement that the English government would be quite unable to take a strong stand against the Russian policy in favor of the Southern Slavs. ${ }^{60}$

The Constantinople Conference, which was made up of the major powers as well as Serbia and Montenegro, came together in December 1876 to discuss a solution to the 1876 war and the Balkan uprisings. Although it was a full year-and-a-half before the opening of the Congress of Berlin, Bismarck had the same apprehensions about this conference as he would

59 Langer, 94.

60 Ibid., 95. 
later have about the Berlin meeting. Bismarck believed that the Constantinople Conference

would bring the existence of the Three Emperors' League into question, as it would inevitably deepen the divergences between Russia and Austria. Germany would be compelled to take sides, which she could not do without hurting one of her allies. Even if the powers came to an agreement, he doubted the success of their action in Constantinople. 61

In many respects, the Constantinople meeting was a showdown between British policy and Russian ambitions. British plans at Constantinople were the same as usual--independence and integrity of Turkey, no special commercial concessions there, a system of autonomy for Serbia and Montenegro, and reforms in Bulgaria. ${ }^{62}$ On the other hand, before the conference began, Tsar Alexander II said in an address to the nobles in Moscow, that "if the conference failed to bring peace, and if he could not obtain the guarantees which he desired from the Porte, he was firmly resolved to take independent action."63 For its part, Austria did not have much respect for the conference, and assumed that a war would inevitably develop after the meeting adjourned. Andrassy only went to Constantinople to prevent Balkan self-rule, as "in that event, the road to Austria's expansion in the east would be closed," especially in BosniaHerzegovina. 64

61 Stojanovic, 99.

62 R. W. Seton-Watson, Disraeli, Gladstone, and the Eastern Question (New York: Barnes and Noble, Inc., 1962): 108.

${ }^{63}$ Buckle, 93. There was little doubt that the Tsar's "independent action" meant war.

${ }^{64}$ Stojanovic, 108. 
It seems that none of the powers present at the meeting had a strong urge to see the conference prevail; "England was the only power directly concerned who was whole-heartedly anxious for the conference to succeed. It rested therefore exclusively upon England's representative to induce the Turks to submission."65 The Ottoman Empire also had a pessimistic view of the meeting. They had just finished thoroughly defeating Serbia and Montenegro, while England had just sent warships to Besika Bay in the Black Sea Straits to show their support for the Turks against Russia. In such a position, the Turks felt no real need to submit to more reforms imposed by the foreign powers. This became especially apparent during the meetings, as when on December 21, 1876, the conference delegates were interrupted by the sound of cannons firing, proclaiming that a new Sultan, Abdul Hamid, had taken power, and he had just granted a liberal constitution, or at least liberal by Turkish standards. With such reforms installed in the new constitution, "the proposed reforms [of the conference] were superfluous [in the opinion of the Turks]"66

Nevertheless, the conference continued. In the end,

the powers as a whole endorsed Salisbury's program, which...created tributary states, favored the status quo in Serbia and Montenegro, and...proposed a large measure of administrative autonomy for Bosnia and Bulgaria. 67

65 Lady Gwendolen Cecil, Life of Robert Marquis of Salisbury, 18681880, vol. II, (London: Hodder and Stoughton, 1921), 112.

66 Buckle, 109-110.

67 Ibid., 108. 
Furthermore, Bulgaria was split into two provinces north and south along the Balkan Mountains. Though the Russians originally wanted to create a single and large Bulgaria like they would attempt in 1878, Ignatiev, the Russian representative, knew that he had little to support such an enormous claim. Thus, he was willing to settle for the next best thing, a divided Bulgaria with a system of autonomy. Furthermore, the division of Bulgaria was seen by the powers as a punishment to the Turks for the crimes committed in the Bulgarian Atrocities. But most significantly, this division of Bulgaria was the first sign of the agreement made at the 1878 Congress of Berlin. However, these plans made at Constantinople never became reality. The new Sultan, Hamid, refused to submit to the Russian and English demands. Thus, "the success of the Russian ambassador was complete...[as now] Russia was left free to make war for which she had been anxious to find a pretext without the danger of protest of any quarter."68 Since the Turks had refused the demands of a united Europe, not even England could justify a war to defend the Sultan. This was exactly what the Tsar was hoping for--a war against the Turks that was sanctioned by the rest of Europe.

When the conference ended on January 20,1877, it did not take long for Russo-Turkish relations to degenerate even more. In addition, "the Russian foreign ministry found itself increasingly under open attack from those in the Russian public and government who wished the resumption of a glorious national policy."69 This was especially the case for the Pan-

68 Rupp, 265.

69 Jelavich, A Century of Russian Foreign Policy..., 172-173. 
Slavists, who were disappointed with the outcome of the Serbo-Turkish War and the Constantinople Conference. They claimed that Russia had been humiliated by the Turks at that meeting, and now it was time to finally strike. But in order to avoid a possible coalition of nations (as in the Crimean War) against Russia in the approaching war, the Tsar worked to guarantee himself a free hand by obtaining foreign approval, especially from Austria-Hungary. Representatives of the two countries met again, and they signed the Convention of Budapest on January 12, 1877. In it, Austria-Hungary promised to "observe benevolent neutrality...and it would take diplomatic action to prevent intervention of other powers [mainly Great Britain]."70 Also, by an "Additional Convention" (not actually signed until March 18, 1877), Vienna "consented to Russia's annexation of Bessarabia, but was in her turn guaranteed the possession of Bosnia and Herzegovina."71 So while Russia obtained Austria's neutrality, the price they paid was very high. For "she [Austria] not only on paper set a bound and limit to Russian advances, but she made it certain that a victorious Russia could not...ignore the claims and vital interests of her hated Danubian rival."72 Perhaps of all the agreements made before the Congress of Berlin, this is the one that was most important. Without German interference, Russia agreed to a limited victory, and this treaty also promised that the Dual Monarchy would gain substantially from the

70 Seton-Watson, "Russian Commitments...," 583. For more details on this agreement, consult this source.

71 lbid.

72 Rupp, 294. 
Russian effort. This is exactly what Tsarist officials would complain about later after the Berlin Congress!

To further secure his position, as war started with Turkey, the Tsar

issued a circular note explaining that he had exhausted all the means in her power to arrive at a lasting peace by a common action with the Great Powers...[and] it was no longer in the interest of Europe to allow the prolongation of such a state of things. ${ }^{73}$

The Tsar knew that Britain could not help the Turks because of the public opinion in England against the Sultan's regime. After the series of atrocities committed by the Turks, and as the Turks continued to refuse true reform, the British public would not have supported a war to prop up such a regime. In fact, the English public actually first supported the Russians, as they believed that the Turks deserved punishment. Prime Minister Disraeli was aware of such sentiment. So with both Great Britain and the Dual Monarchy neutralized, "Russia began a Turkish War in...favorable circumstances,...never had the diplomatic field been so well prepared."74

${ }^{73}$ Stojanovic, 155.

74 Ibid., 150-151. 


\section{CHAPTER IV}

THE RUSSO-TURKISH WAR, 1877-1878

The Tsar gave one last effort to force reforms on the Ottoman Empire with the proposed London Protocol, which was signed by the other European powers on March 31, 1877. Basically, it was the same plan as adopted at the Constantinople Conference, with a few variations and with different deadlines for administration of the reforms. However, the Sultan refused to accept this idea, and the long-awaited Russo-Turkish War soon became reality. ${ }^{75}$ The Tsar's patience had worn out, and satisfied that the Turks would receive no outside help, he declared war on the Ottoman Empire on April 24, 1877.

Russian troops had been preparing for battle for sometime, as they had massed two forces (one at the Rumanian frontier, and one in the Caucasus) for an invasion into Turkey. While the latter army was to push as far into Armenia as possible and also secure the eastern coasts of the Black Sea, the other force looked to advance as quickly as possible into the Balkans, with the city of Constantinople as their ultimate goal. After some delays due to poor planning and execution, the first offensives were very successful, especially into the Balkans. Rumania, which was still an autonomous region of the Ottoman Empire, had helped the Russian cause 
by allowing passage of Tsarist troops. However, that in itself was a very complicated situation and will be discussed later.

The British government was divided on its policy concerning the war. Disraeli did not favor intervention on the side of Turkey unless England's most vital interests were at stake. ${ }^{76} \mathrm{He}$ was still upset about the Sultan's negligent attitude towards the reforms asked for by the powers, and he was also aware of the dislike that the English populace had for the Turks at this time, especially after The Bulgarian Atrocities. But Queen Victoria was much more determined to meet the Russian advance, as the strategic location of Turkey was still the key consideration for her. On the eve of the war, the Queen

$$
\begin{aligned}
& \text { appealed to the feelings of patriotism...[and] the absolute } \\
& \text { necessity of showing a bold and united front to the enemy } \\
& \text { in the country as well as outside it [the British } \\
& \text { Empire]... It is not the question of upholding Turkey; it } \\
& \text { is the question of Russian or British supremacy in the } \\
& \text { world! } 77
\end{aligned}
$$

But after much deliberation, England decided to maintain a policy of "watchful and conditional neutrality," naming British interests in Turkey, Constantinople, Egypt, and the Suez Canal as off limits to Russian ambitions. ${ }^{78}$ Meanwhile, Austria hoped that the Tsar would limit Russia's gains to those promised in the Treaty of Budapest.

The initial Russian successes concerned the English, as it appeared that they had misjudged Russian troop strength. Soon, London was

76 Buckle, 192.

77 Ibid., 133. The full text of the Queen's statement is available in this source.

${ }^{78}$ Rupp, 371. 
making preliminary plans to ship a force, possibly involving also Austrian troops, to help defend Constantinople.

Disraeli wanted the support of the Austrian army to make it clear to Russia that she would have to counter with armed resistance to Austria and Great Britain if she occupied Constantinople or refused to accept revision of her terms. ${ }^{79}$

However, just when the situation appeared lost, Turkish forces made a valiant stand at Plevna in mid-July, 1877, and stopped the Russian advance. The Turks withstood two onslaughts there and then went on their own offensive in August, successfully pushing back Russian lines. Suddenly the immediate danger to Constantinople was diminished and the war dragged on towards an uncertain duration and conclusion. England was naturally very relieved by this news, as the Russians had suffered a significant defeat at the hands of the Turks.

In the meantime, for the Pan-Slavs, this war

gave fresh impetus to the agitation of the Slavophils, who considered this war as their own work and believed that it was undertaken for the Slav Idea. Popular excitement stimulated by the press and at meetings was now general. Alexander II was hailed as the Tsar of all Slavs, whereas Europe was fiercely attacked. ${ }^{80}$

Such a campaign worried Austria-Hungary, as Andrassy hoped that such emotions would not engulf the Slavs within the Dual Monarchy.

A new Russian offensive in the Balkans had to wait until September 1877 in order for the troops to regroup. To make sure that they would succeed in their next attempt, the Tsar's agents had been busy negotiating

79 Stojanovic, 219. This would not be the last time when a joint AngloAustrian action was proposed by England against Russia in 1877-1878.

80 Ibid., 154. 
a military alliance with Rumania. Ever since the start of the war, Rumania had wanted to participate, but the Tsar had shunned all proposals for such an alliance, as he had not wanted any obstacles in the way of obtaining the Rumanian territory of Bessarabia. But officials in Bucharest knew of Russia's desire for Bessarabia, even though the Russians had never openly expressed these desires. This situation "caught the Russian diplomats in a most difficult dilemma. They needed Rumanian cooperation in any military advance against the Turks, but they also wanted a part of Rumania's territory." 81 A convention had already been signed in April, 1877, which included the Russian pledge "to preserve and defend the then territorial integrity of Rumania." 82 But the agreement never included Rumanian participation in the war on the side of Russia. However, after the loss at Plevna, the Tsar, needing more troops, offered Prince Charles of Rumania the command of military operations. Charles accepted this post, and abandoned "his previous demand for action. It should be noted that he also did not use the opportunity afforded by the Russian embarrassment to gain precise advantages [Bessarabia] for his country." 83

With the addition of Rumanian troops, Russian forces again besieged Plevna. Despite another strong Turkish defense, the Sultan's armies were

81 Jelavich, "Southern Bessarabia...," 204.

82 R. Rosetti, "Rumania's Share in the War of 1877," The Slavonic and East European Review 8 (1929/1930): 550-551. This agreement also allowed free passage of Russian troops, which was necessary for the initiation of the war. Consult this article for the full explanation of the Russian-Rumanian Convention of April 1877.

83 Jelavich, "Southern Bessarabia...," 216. 
badly defeated in late November, 1877. This sealed the fate of the Turkish cause. "The Russian army now pushed on at once to Adrianople...there was no longer any Turkish army worthy of opposing Russia's march."84 By January 1878, Tsarist troops had advanced practically unopposed all the way to Adrianople. This stirred Britain into action, as the fleet was ordered to go through the Dardanelles and into the Sea of Marmora on January 23. In an effort to calm London, Russia signed an armistice with the Sultan in Adrianople on January 31. Even this did not fully quiet England, as parliament appropriated six million pounds for military preparations in early February, and

for two months thereafter, there was a clear likelihood of war between Britain and Russia. Much hinged on the outcome of the Russo-Turkish negotiations [for peace] and on the Russian troop movement in the neighborhood of Constantinople. ${ }^{85}$

The Tsar countered the movement of the British fleet by sending his troops to the town of San Stefano, about eight miles from Constantinople. Finally, within sight of the Holy City of Eastern Orthodoxy and St. Sophia Cathedral, the Treaty of San Stefano was signed between Russia and the Ottoman Empire on March 3, 1878, signifying the official end to the almost year-long war.

Basically, the Treat of San Stefano's

most important feature was the creation of a new large Bulgarian state, larger than that of the Constantinople Conference, and possessing [an] Aegean Sea coast....In addition, San Stefano proposed an increase in territory for Montenegro and for Serbia, which was also to become

84 Rupp, 216.

85 Clayton, 141-142. 
totally independent, as was Rumania. Rumania was to cede Southern Bessarabia to Russia, and to receive in compensation the Dobrudja region. In Asia, Kars, Batum, Ardahan and Bayazid were to become Russian; and Turkey was to pay a large indemnity. ${ }^{86}$

But the treaty also

corresponded to two fundamental tendencies of Russian policy: it satisfied the Slavophils, who desired to see as many Slavs as possible liberated; it...established her domination over the Straits and expelled Austria from the Balkan peninsula. ${ }^{87}$

The author of the treaty was the Russian Ambassador to Constantinople, General Count Nicholas Ignatiev. The general had been at Constantinople since 1861, and had served Russia there in many capacities. From the very first, he was an ardent Pan-Slavist, as he "saw in the Slavophile movement only an expression of national self-consciousness and looked on all Slavs outside of Russia as natural allies against the increasing aggressiveness of the regenerated Teutons." 88 Before 1878 , the Tsar was reluctant to promote many Pan-Slavists to his staff, as this would only add extra pressure on him to embark on an extremely adventurous foreign policy in the name of Pan-Slavism. But the fact that Ignatiev was chosen to negotiate this treaty gave the Pan-Slavists hopes that the Tsar was coming more under their persuasion. The terms of this treaty reflected Ignatiev's definite Pan-

86 Ibid., 143-144. The indemnity amounted to about one-point-four billion rubles, an enormous sum, but it was designed to rectify Russia's dire financial straits after the war. Again, there are more specific terms of the treaty not explained here.

87 Stojanovic, 233.

88 Leonid I. Strakhovsky, "General Count N. P. Ignatiev and the PanSlav Movement," Journal of Central European Affairs 17, no. 3 (October 1957): 255. 
Slavist beliefs, and for this reason, San Stefano has been called "the climax of his diplomatic career." 89

But while the Russian nationalists and Pan-Slavs were jubilant for the treaty, reaction abroad was stern and swift. For one,

these terms, which gave Russia apparent predominance in the Balkans and a strong position in Asia, were in flagrant contradiction with other European treaties, notably the Treaty of Paris and the Reichstadt and Budapest Agreements. 90

Beyond just the legal aspects, the peace treaty really threatened England's and Austria's vital interests. The establishment of a large Bulgaria (designed to be a Russian satellite) with access to the Aegean Sea would mean the emergence of Russian naval power in the Mediterranean Sea, potentially threatening passages to India through both the Straits and the Suez Canal. Though the Straits to the Black Sea did not provide a direct path to India, the eastern shores of the Black Sea placed one in close proximity of the Persian Gulf and India by a land and river route. So if the Russians controlled the Black Sea, then this would cut the British off from using this possible path towards India. Also, the British thought that the treaty put Russia in such a dominating position over Turkey, that the Sultan's actual independence would be virtually non-existent, leaving him constantly subject to blackmail.

For the Dual Monarchy, the creation of a large Slavic state, though not actually touching her borders, was feared, and was also regarded as a violation of their agreements with Russia, especially the recent one signed

${ }^{89}$ Clayton, 144.

90 Jelavich, The Ottoman Empire..., 111. 
at Budapest. Thus, "both Austria-Hungary and Britain were now pressing for a fundamental revision of San Stefano, and in Britain's case, there was a clear warning that war might follow unless the Russians agreed to a conference." 91

To show that they meant business, the British fleet remained in the Sea of Marmara, within firing range of the Russian force, which was encamped in the town of San Stefano. England intended to remain there until a satisfactory arrangement was made for a conference. In the meantime, tensions remained very high as each side waited for the other to make a move. It was here that the German Chancellor Bismarck took the lead in working on a peaceful arrangement between England and Russia. Bismarck increasingly recognized that he needed to prevent a general European war, as he feared that Germany would become involved, even if it really did not want to do so. While the two forces confronted each other, Bismarck contacted both sides in order to familiarize himself with each party's ideas, and then work for a compromise. In order to assert his own position, Bismarck, in a speech to the Reichstag on February 19, 1878, "announced that Germany sought only to be the 'honest broker'," thus presenting himself as a neutral mediator in Balkan affairs.92 But the situation was still very tense, as both England and Austria discussed military preparations and an alliance.

A conference to solve the problem was first proposed by Austrian Foreign Minister Andrassy, but the Russians refused his suggestion it be
91 Clayton, 144.
92 Rupp, 458. 
held in Vienna, as they knew that a meeting held in the Habsburg capital could provide Austria-Hungary with possible advantages in any negotiations. Finally, in early March 1878, Russian Foreign Minister Gorchakov proposed a Congress to be held in Berlin. The other powers agreed, though

Germany and England accepted Berlin with some reluctance. Bismarck disliked being compelled to take a more active part in the settlement of peace than he wished to; England feared lest it might lead to a more intimate cooperation between the three Northern Powers. ${ }^{93}$

The powers agreed to the Congress only if it limited itself to the issues dealt with in the Treaty of San Stefano and the Russo-Turkish War, "excluding from it, Egypt, Syria, and the Far East and some others."94

Russia was still very reluctant to see the entire treaty shelved by a Congress, and Gorchakov soon appeared to want to distance himself from his own proposal for a meeting. In the meantime, the three major parties, England, Russia, and Austria-Hungary, continued to place proposals and positions before each other, while military preparations also went on until late May. The Tsar soon realized that Russia was completely isolated, and that it was in no position to fight a war, as its military and finances were exhausted. Using Bismarck as a middleman, England and Russia decided to negotiate the issues and resolve their differences prior to the forthcoming Congress. Lord Salisbury represented England in these negotiations. He

93 Stojanovic, 235.

94 Ibid., 236. This was the demand made by France, which was accepted by the other powers as a condition for a Congress. 
had recently become foreign secretary following the resignation of Lord Derby, who had lost his credibility after the Treaty of San Stefano.

Thus, in a May 30th protocol, Russia's Asian conquests were restored to Turkey, except for Batum and Kars. Also, Bulgaria was divided into two parts by the line at the Balkan Mountains, as the agreement made at the Constantinople Conference had recommended. "In return, England consented, though with reluctance, to Russia's taking Bessarabia, and promised not to contest the other clauses of the Treaty of San Stefano."95

This protocol was quickly followed by an agreement between Britain and Turkey. Since Russia was to retain Batum and Kars, England did not feel completely safe from the risk of another Russian invasion into Turkish Asia or Persia. Accordingly, Turkey and England signed the Cyprus Convention of June 4, 1878. In this agreement,

the British government would defend by force of arms the Sultan's Asiatic dominions, as demarcated by the Congress, against any fresh Russian attack. In order to be in a position to execute this engagement, the English were to be allowed to occupy and administer the island of Cyprus, paying annually to the Sultan. ${ }^{96}$

This brought about a desired outcome for England, because as their empire expanded in Africa and Asia in the 1870's, there had been shown the need to acquire a port either in the Black Sea or in the Eastern Mediterranean which would provide Great Britain with a naval base closer to Suez and the Straits

95 Tbid., 255-256. For some specifics on this protocol, consult this source.

96 Buckle, 298. Again, there are more detailed provisions within this agreement, and they are explained in this source. 
than Malta...[and thus], the lines of imperial communications would be assured. ${ }^{97}$

The last pre-Congress arrangement came on June 6,1878 , when "Britain and Austria-Hungary made a preliminary agreement concerning the new Bulgaria and the Austrian position in Bosnia...[but] common ground between Britain and Austria-Hungary was limited to Turkey in Europe."98

Hence, at last, the issues before the Congress were decided upon, and perhaps more importantly, many problems were solved by the pacts involving Russia, Great Britain, Austria-Hungary, and Turkey. For this reason, author William Langer pointed out that some historians have said that "the Congress of Berlin was at bottom a farce, because all the decisions had been made beforehand."99 However, Langer disagreed with this opinion. He stated that

Bismarck would have been only too glad if this had been true...the agreements made beforehand were all of a vague nature, and all of the powers chiefly concerned were determined to get what they could out of the Congress. ${ }^{100}$

This is a crucial element to keep in mind for the Congress of Berlin, as it seems to have been a commonly held attitude, especially by Russia. Despite all of the preliminary agreements that it had with England and Austria-

97 Jelavich, The Ottoman Empire..., 113. Many historians treat the Cyprus Convention as a separate matter from the Congress. A special monograph has been written on it: Dwight E. Lee, Great Britain and the Cyorus Convention Policy of 1878 (Cambridge, Massachusetts: Harvard University Press, 1934).

98 Clayton, 145.

99 Langer, 153.

100 Ibid. 
Hungary, the Tsar still wanted the most out of the Congress that he could get, and he looked to Germany to help him achieve it. In his view, Germany owed Russia a favor for staying neutral in Germany's wars of unification. Now it was time to return those favors. At the same time, agreements outlying the general focus of a major conference were (and still are) very common, as it was necessary to limit the discussions to a definite field, otherwise delegates could force such complicated negotiations, that the whole meeting would have been in danger of failure. Such high-level meetings were showcases, where diplomats came in their best possible positions, while still pursuing an eventual agreement. Thus, with the stage set, a vast array of distinguished personalities convened in Berlin for the historic Congress of Berlin. 


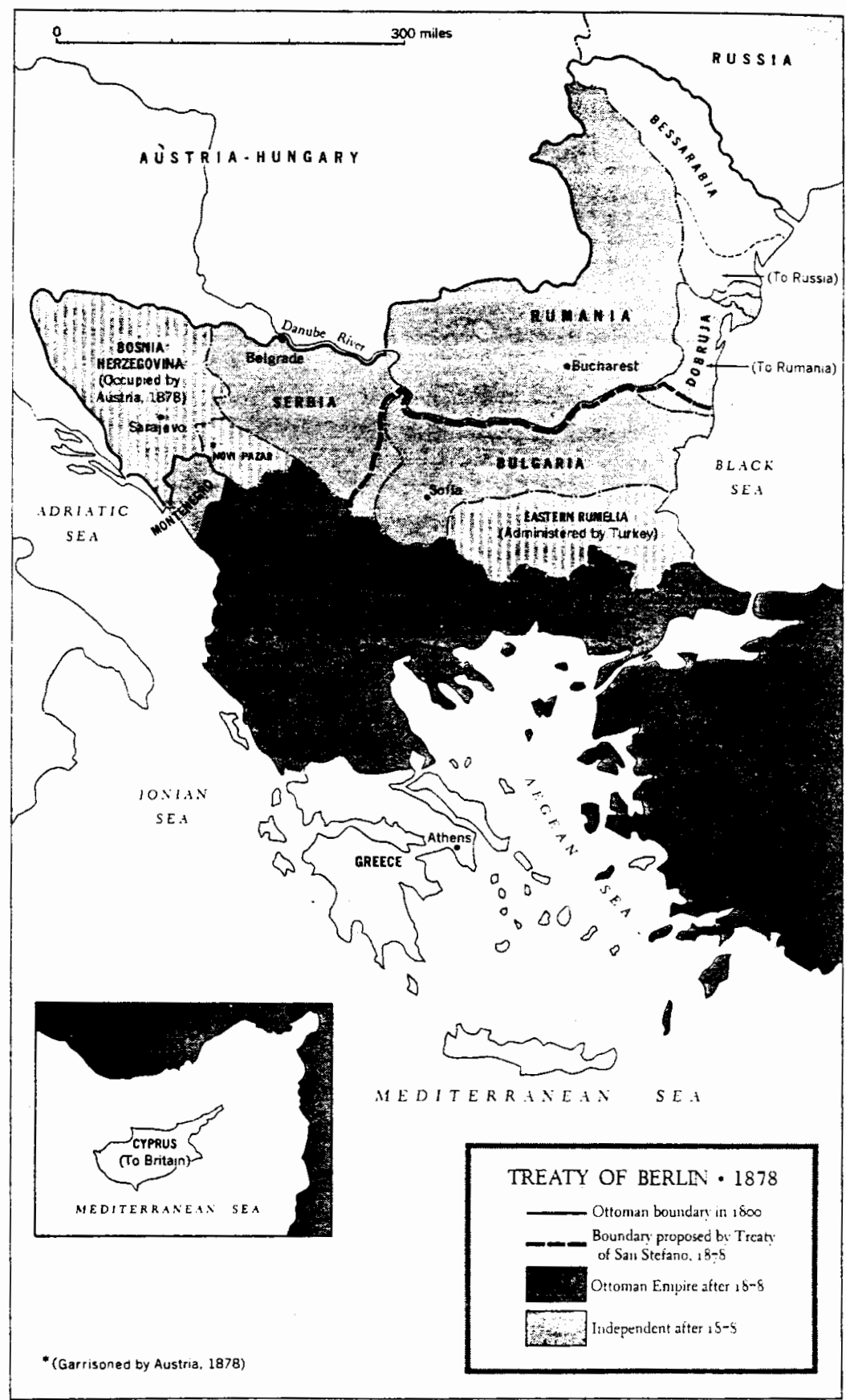

Figure 1. Map of Treaty of San Stefano, 1878 and Treaty of Berlin, 1878. Source: Norman Rich, The Age of Nationalism and Reform 1850-1890. 2d ed. (New York: W. W. Norton and Company, 1977), 234. Reproduced by permission of the publisher. 


\section{CHAPTER V}

\section{THE CONGRESS OF BERLIN OF 1878}

The Congress, which convened on June 13,1878, "was one of the most brilliant political assemblies of modern times, not unworthy of comparison with the congresses of Vienna and Paris."101 But unlike these previous congresses, never before had there been so many nations with the distinction as a Great Power; and Berlin included dignitaries for peoples that were not represented at the other meetings.

The British delegation, possibly the most competent of all the groups, included Prime Minister Benjamin Disraeli, Foreign Secretary Lord Robert Salisbury, and the English Ambassador to Berlin, Odo Russell. They were most set on changing the Bulgaria created in the Treaty of San Stefano, and were even willing to make some minor concessions in Asia to do it. Yet in many respects, they were in the best position of all the powers, as it was mostly their determination that brought on the Congress, and also, they were the most prepared for war.

Russia countered with the veteran Foreign Secretary Alexander Gorchakov, who was obviously past his prime, not to mention the fact that he and Bismarck had experienced a strained relationship for several years. The Russian Ambassador to London, Count Peter Shuvalov, thus, stepped to the forefront of their delegation. Also, the Ambassador to Germany, 
Count Paul Oubril, attended, but he made no real contribution. Notice that Count Ignatiev, the creator of the Treaty of San Stefano, did not come to Berlin. This showed that even the Russians realized that the treaty "was the greatest stupidity that we could have made."102 Nevertheless, the Russians, especially Gorchakov, still hoped that a "Big Bulgaria" could yet be saved during the meetings.

Austria-Hungry sent a respectable delegation, consisting of Foreign Minister Andrassy, the Austrian Ambassador to Berlin, Count Alois Karolyi, and Baron Heinrich Haymerle as an adviser. Their policy was set on acquiring the Turkish provinces of Bosnia-Herzegovina, and they looked to England and Germany to support their cause.

Although France swallowed its pride by coming to Berlin for such a meeting, it sent her Foreign Minister, William Waddington and her ambassador to Germany Count Saint-Vallier, and Dèspres as an adviser. The French took a very cautious course in Berlin, and saw themselves as a second mediator to Germany.

Meanwhile, Italy was represented by Foreign Minister Lodovico Corti, an experienced diplomat, and Count de Launay, the Italian ambassador to Berlin. The Italians hopes to show their new strength by gaining some kind of prize in the disintegrating Ottoman Empire, and mostly followed Britain's lead to do so.

The Turks sent delegates as well, yet they did not bother to send a strong contingent to a meeting that would prove to be a humiliation. Their

102 Medlicott, The Congress of Berlin..., 40. This was a statement that Shuvalov made before the Congress met. 
main goal was to leave Berlin as little damaged as possible, and they, too, looked to England for help.

The small Balkan states also sent representatives, none of whom are important enough to name, primarily because they came as observers who could make appeals and suggestions, but they did not have real voting power. On a whole, "nationality as a principle found little, if any, sincere support from the Great Powers."103 Instead, political and strategical considerations were given top priority.

Although the German delegation included their Foreign Secretary von Bernhard Bülow and the Ambassador to Paris, Prince Chlodwig Hohenlöhe, there was no doubt that Bismarck was definitely the dominant member of this contingent, and, in fact, of the whole Congress. Knowing his expertise, the representatives quickly elected him as president of the Congress, even though this created a situation the chancellor wanted to avoid. He knew that both Russia and Austria expected him to vote for their side, and he did not want to be placed in that dilemma in the presence of all the other diplomats. In order to avoid this, he even suggested that French Foreign Minister Waddington be elected as president of the proceedings. Somehow, Bismarck needed to bring the Congress to a successful conclusion, and at the same time, satisfy all of the participants. This was especially the case with Russia and Austria-Hungary, since Bismarck wanted to maintain the Three Emperors' League. In nominating Waddington, the German chancellor tried to put France in a place of responsibility, especially if either of the other Northern Powers' goals failed

103 Henry F. Munro, The Berlin Congress (Washington D.C.: Government Printing Office, 1918), 30. 
to be realized. However, the delegates did not want it, and Bismarck became president of the Congress. His role became crucial in making the meeting a success. In all, "twenty representatives...participated, three from each of the powers invited, save Italy, which sent only two."104

Despite all of the preliminary agreements, the Congress' main goal was still to change the unpopular Treaty of San Stefano, and "to secure in the interests of European peace, the creation of a reorganized Turkish Empire which should depart from the status quo...as little as possible."105 However, since there were many questions to resolve in the treaty concerning Europe and Asia Minor, which ones would get priority? Bismarck answered this in short order, as he saw Europe in a very tense situation. He took the initiative with the statement, "let us deal with the great things that concern England, for England is quite ready to go to war with Russia."106 No one could deny this, and so at only the second meeting of the Congress, the delegates moved to resolve the most pressing issue first, the "Big Bulgaria" created at San Stefano."107

The "Big Bulgaria" consisted of many problems, especially in the opinion of England and Austria-Hungary. The new Bulgarian coastline touched both the Black Sea and the Aegean Sea, and since the new nation would presumably be a Russian satellite, this would allow the Russians to

104 Ibid., 8.

105 Medlicott, The Congress of Berlin..., 133-134.

106 Buckle, 315.

107 As the Congress started, Salisbury wrote in a letter, "if this Bulgarian question can be satisfactorily settled, all the other matters will quickly find their level [of importance]." Cecil, 281. 
avoid the Straits into the Black Sea, and give the Tsar's navy direct access to the Mediterranean Sea by using Bulgarian ports. This would solve the long-standing problem of the Russian Navy being bottled up in the Black Sea. But as long as the British controlled the Straits and the Mediterranean Sea, they could not allow the Russians to pose such a threat. Allowing the Russians a port in the Aegean Sea also would endanger England's route to India, as Russia could conceivably blockade both the Straits and the Suez Canal. Naval concerns were not the only problem involved in the "Big Bulgaria." Her new borders included many peoples besides Bulgarians. Greeks, Turks, and other Slavic peoples would find themselves inside the new state, mostly against their will. Western Europeans attached special significance to the Greeks, because of their cultural and historical importance and, thus, did not want them included in the projected borders. Likewise, the nationality problem was of great concern to AustriaHungary, since the new Bulgaria represented the realization of the large Slavic state which they so dreaded. Andrassy argued that the "Big Bulgaria" violated the Budapest Agreement of 1877, in which Russia had promised not to create such a large Slavic state. Britain also stipulated that these new borders would threaten the Ottoman Empire, reducing it to a puppet state of St. Petersburg. With most of the other powers agreeing with these criticisms, Russia had little chance of maintaining its dream of a "Big Bulgaria." In fact, all the Great Powers followed England's lead on the Bulgarian issue. Even the Balkan representatives at the Congress did not support the "Big Bulgaria," because the proposed state included lands which the other Balkan states also wanted. 
Thus, the discussions turned to redrawing the Bulgarian border at the Balkan Mountains, with the Sultan maintaining political and military control of the southern province (East Roumelia), a system adopted at the Constantinople Conference. However, the situation had changed, as the Russians had just won a costly war, and for that reason, the Russian delegation at first refused to consider a small state. They also did not want the Turks to regain East Roumelia, even if the area was to be autonomous. Thus, when Shuvalov sent the new proposals to the Tsar for consideration, the British made arrangements for a special train to take the English delegation home on June 21. Bismarck intervened here, as he saw the Congress collapsing before his eyes. In order to save the Congress, Bismarck had dinner that night with Prime Minister Disraeli, and they discussed both British demands and possible concessions. Later, with French mediation, it was decided "that the Sultan might garrison troops on the frontier between East Roumelia and Bulgaria, but not billet them on the population ...[and] The Russian occupation of Bulgaria was to be limited to nine months." 108

This agreement then helped solve several related problems at the same time. While the smaller Bulgaria was to receive independence, the Sultan received political and military control over Eastern Roumelia under four main conditions, though that province was also to exercise a great deal of autonomy. 109 Russian troops were to help establish a new government in

${ }^{108}$ Langer, 155.

109 Medlicott, Congress of Berlin..., 56. The Sultan was given very strict guidelines on how he could use his troops here, including the requirement of informing the Great Powers when he chose to do so. See the limitations cited here. 
Bulgaria, and eventually in April, 1879, the Bulgarian Assembly elected as their hereditary prince, Alexander of Battenberg. For

the Treaty of Berlin had excluded from the throne members of the Russian ruling family, but...he [Alexander of Battenberg] was a German prince, his father had served in both the Russian and Austrian armies, and he was related by marriage to the English royal family. In short, his election could be counted upon to win general approval.110

However, the Russians soon became disenchanted with the prince, as he pursued a foreign policy very different from that of the Tsar, and before long, Russian officials looked for ways to remove him from office.

As for the rest of the Bulgarian settlement at Berlin, the Turks were given permission to fortify the border on the southern side of the Balkan Mountains for necessary security. This breakthrough still left the borders "in somewhat vague terms, it was agreed that it [the borders] should be left to a technical commission which was to base its decisions primarily on strategic and geographical considerations." 111 Later, as the Congress neared an end, the representatives accepted the borders as suggested by the commission. The division of Bulgaria into two parts and the decision on its government was a great victory for England which received aid in this, as "Andrassy's vigorous and consistent support of the British was...the decisive factor in the situation." 112 However, there was a price for this support, namely that England would support Austria-Hungary's desire to

110 Langer, 336.

111 Medlicott, Congress of Berlin..., 56-57.

112 Ibid., 57. 
occupy Bosnia-Herzegovina. These provinces became the next question to be considered by the Congress.

Since the start of the Balkan uprisings in 1875, the Dual Monarchy had become increasingly interested in acquiring these two Turkish provinces to the south. Andrassy had been long reluctant to do so, as this would only have brought more Slavs into the monarchy, something which he and his fellow Hungarians did not really want. But after the Turk's decisive loss to Russia in 1878, there was no longer any hope of the Sultan maintaining his hold on either province. This meant that either AustriaHungary would gain Bosnia-Herzegovina, or they would be divided up between Serbia and Montenegro. The latter was not acceptable for Andrassy. He still looked for a way to secure the regions without outright annexation. In the time preceding the Congress, Andrassy had approached the British with the idea of establishing a military occupation of Bosnia and Herzegovina, and since the Dual Monarchy supported England's proposals on Bulgaria, this seemed a reasonable trade. Moreover, both the Sultan and the Tsar could approve an occupation of the two provinces, because an occupation was not as definite and final as an outright annexation. Thus, on June 28th, it was Salisbury who proposed the occupation idea, after Andrassy had described the bad conditions in the provinces.

However, both Turkey and Russia resisted the proposal. The Turks were still opposed to any further loss of territory, no matter how it was done. Salisbury himself "described the occupation as a 'left-handed annexation'."113 The Turkish refusal on this matter continued until July 
13, when Andrassy secretly declared "that the occupation would only be temporary, and expressly reserving legal sovereignty over the provinces to the Sultan...the final details were reserved for a separate Austro-Turkish agreement."114 Such an agreement did not actually come until April, 1879.

Russia was equally interested in the territorial settlement in neighboring Montenegro. Shuvalov "emphasized the great importance which Russia attached to a satisfactory solution of this question." 115 This attitude actually showed the difficult position into which the Russians had brought themselves. The Treaty of San Stefano had not only caused united opposition from the west, but also most of the Balkan peoples resented it. While Russia had spoken eloquently in past years about Slavic unity, the borders drawn at San Stefano satisfied the Russians, but only aroused mistrust among the Slavs. Too many people would end up in a country with a different nationality, and, small Slavic nations feared the large and possibly ambitious Bulgaria that Russia wanted to create. After the Treaty of San Stefano, all the Slavic nations but Bulgaria and Montenegro looked to the west for protection. Russian officials realized this, and put special emphasis on helping the cause of Montenegro. In order to win Russia's approval of Austrian occupation of Bosnia-Herzegovina, Montenegro was allowed to win some concessions. However, even the settlement in Montenegro had to please the Dual Monarchy.

Montenegro had secured the recognition of her independence and a few miles of coastline, but was not allowed to have vessels of war...and [they] had to

114 Bridge, 92-93.

115 Medlicott, The Congress of Berlin..., 43. 
surrender the greater part of the territory allotted to her by the San Stefano Treaty. ${ }^{116}$

Also, the Austrians proposed to place an army garrison in the Sandjak region. "The Sandjak was to Bosnia and the Herzegovina what the Straits were to the Black Sea: a gateway to the east which must be kept open."117 The Sandjak was vital for communications between the Dual Monarchy and the two occupied provinces. If the region fell to a Slavic state, the Habsburg armies would be in potentially serious danger. This region, too, was included as an area for Austro-Hungarian occupation.

The Congress of Berlin also dealt with problems affecting many other nations of Southeastern Europe. One of the tragic but realistic decisions made at the meeting concerned Rumania and the region of Bessarabia. No one could doubt the Rumanian contribution to the Russian victory over the Turks, especially in the November 1877 campaign at Plevna, where extra Rumanian forces helped the Russians break the determined resistance of the entrenched Turkish forces. In fact, the Rumanians declared independence in May, 1877, and "although the move was greeted with great enthusiasm within the country, it received a negative reception abroad."118 Their declaration of independence was not recognized by anyone, for the western powers knew that then the war started, that Russia would most want to gain Bessarabia as compensation. And yet if the province fell

116 Ibid., 96-97.

117 Bridge, 97. Included in the garrison was the entire area known as the Sandjak of Novibazar, an important passage in the Balkan Mountains, which was necessary for an army to maintain while in BosniaHerzegovina.

118 Jelavich, "Russia and...Southern Bessarabia...": 215. 
under Russian control, the Tsar would be pleased and the west would not be threatened. If the powers had recognized Rumanian independence, then the Russians could not have obtained Bessarabia from the Sultan, since it was actually Rumanian territory. Then if the Russians occupied Rumania in order to finally obtain Bessarabia, how would the Great Powers be able to help them other than through war? No power was willing to go to war to protect Rumania. Finally, at the Congress itself, the Rumanian representatives, Brătianu and Kogălniceaneu, pleaded their case. Though they found sympathy, no one was willing to support them, mainly because of the problems surrounding Bessarabia. Perhaps this decision, more than any other, showed that the delegates at the Congress had adopted Bismarck's plan of partitioning the Ottoman Empire between the powers, in order to satisfy the Great Powers and avoid a possible war. Concessions for nationalism did not fit into Bismarck's partition plan. This is another example of Bismarck's habit of practicing the power politics involved in Realpolitik, which, in his mind, only included the Great Powers as noteworthy for consideration.

So while the Russians finally realized their long dream of reacquiring the strategic and lush region of Bessarabia, the Congress looked for ways to soothe Rumanian disappointment. Therefore, in compensation for the loss of Bessarabia, the Rumanians obtained recognition of their independence and the region of Dobrudja, a strip of land south of Bessarabia. However, there was little comparison between the two regions, as Bessarabia was an area of rich soil bordering part of the Danube River, while Dobrudja had little if any value. Nonetheless, the Rumanians had to accept what they were offered, but after this experience, "distrust [of 
Russia] became the foundation of Rumania's foreign policy in the following decades." 119

While Montenegro received small gains along the Adriatic coastline, some adjustments to Serbia's borders were also made, though far less than they would have obtained from the Treaty of San Stefano. However, both states were granted outright independence, and were no longer required to pay tribute to the Sultan. Meanwhile, Greece acquired some regions in Macedonia that were not granted to Bulgaria. Therefore, while the small Balkan states did gain some territories at the Congress of Berlin, it was for the most part less than they would have received by the San Stefano Treaty. At the same time, the Balkan states were generally pleased with their treatment at Berlin, while some had actually been outraged at the Russians for their treatment at San Stefano. The diplomatic reversal tended to create strong relationships between most of the Balkan states with the western powers, at least on a temporary basis.

The fact that Russia acquired the strategic province of Bessarabia raised the problem of controlling the mouth of the Danube River. This was a serious problem, especially for Austria-Hungary, which depended on the Danube River for much of its commerce. Needless to say, the control of the river had important military implications as well. As long as the Turks controlled the mouth of the Danube, and as long as the Habsburgs had good relations with them, the Danube was considered safe. However, with Russia in control of the river's mouth, a new system was necessary that could satisfy everyone.

119 Rosetti, 569. 
Instead of placing the river under the domination of one country, the Danube was made neutral below the Iron Gates. To govern the river, a European Commission, created in the Treaty of Paris of 1856, was reestablished, this time composed of Austria-Hungary, Russia, and Rumania. The Dual Monarchy was given the authority to assume the responsibilities of maintaining the Iron Gates, keeping the river navigable, and collecting tolls from all ships at the Gates. Eventually, this European Commission was made a permanent body in 1883 . "The settlement was thus a Habsburg victory throughout." 120

A British-Russian confrontation resurfaced at the Congress concerning the control of the Bosporus and Dardanelles, which connect the Black and Mediterranean Seas. For centuries, Russia desired to have the Straits, but always had been denied that wish in some way or another. Great Britain had usually been the main force behind the protection of the Straits. In 1878 , Russia had come very close to capturing the city of Constantinople, and with it, the strategic Straits. But after the "Big Bulgaria" was lost at the Congress, and with it, Russia's bid to control the Straits, the Russian delegation at first pressed for the Straits to be opened to all warships. However, this would have actually been detrimental for the Tsar, because the British could come in and threaten Russia's Black Sea fleet and cities. British dominance of the seas was well known, and on the other hand, between 1856 and 1871, the Russians had not been able to station a fleet in the Black Sea, so the Tsar's naval presence there in 1878 was still small. Hence, the Russians soon realized that leaving the Straits

120 Jelavich, The Qttoman Empire..., 123. 
closed to all warships at least secured the Russian position on a short term basis. Therefore, on July 11, Shuvalov agreed that "the closure of the Straits is a European principle, and that the stipulations laid down in this matter in 1841,1856 , and 1871 , now confirmed by the Treaty of Berlin, are obligatory upon all the powers."121 And so with this decision, the control of the Straits remained with the status quo: in the hands of the Turks, and with no advantage to any one power.

Another difference between Russia and Great Britain concerned some of the regions and cities in Asia Minor that Russian armies had conquered in the Russo-Turkish War. The fact that Russian territory and influence was growing ever southward concerned the English, who knew that Russia desired to have access to Persia and the Persian Gulf, in order to obtain a warm water port. This would be especially important if the Tsar was unable to gain control of the Straits into the Black Sea. The possibility of the Russians acquiring a Persian Gulf port would seriously threaten Britain's position in India, and would surround the Ottoman Empire in a vise. Though this was still only a possibility, when the Tsar moved into some key positions along the Black Sea and into Northern Armenia, it was a sure sign of his long-term intentions. The most important city that the Tsar claimed was Batum, a crucial city on the Black Sea, especially if it were used to its military potential.

However, the British delegates recognized that they had already received nearly every demand that they desired from the Congress, and they were "willing to admit that the acquisition of Batum...did not 
constitute in itself an adequate ground for war."122 This was especially the case, since the Straits had been secured. Thus, a compromise was reached concerning Batum. Russia was allowed to keep the city of Batum, but it was "to be free and exclusively commercial."123 In this manner, the Russians would be satisfied in gaining Batum, but in having it, the city would not prove to be of a military danger to England's position in India. And along with Batum, Russia also gained Kars and Ardohan in Armenia, without any restrictions.

As an added measure of insurance against Russian advances, the British came to a conclusive agreement for the acquisition of the island of Cyprus in the Eastern Mediterranean. This gave England more credibility in its claim to protect the Turks from further threats. That is, the Sultan would have a firmer control of a smaller region, which would seemingly be better than only weak control of a vast unstable empire.

The only other area that the Congress touched upon was Tunis, as it appeared that since the British had acquired the controlling shares of the Suez Canal in 1875, then Egypt would soon become part of the British Empire. The French were not too pleased with this prospect, especially since they helped finance the canal. So, "Bismarck...apparently suggested to the English the possibility of squaring the French by leaving them a free hand in Tunis...Waddington returned to Paris contented to have Tunis in his pocket."124 Though no formal arrangement was made at Berlin

122 Medlicott, Congress of Berlin..., 105-106.

123 Buckle, 338.

124 Langer, 160. 
concerning Tunis, France was convinced that the area would soon be theirs. Since Tunis was to be assigned to France, this meant that the Italians' best hope of gaining something at Berlin came to naught.

At last, on July 13,1878, with all of the delegates in full dress uniforms, the Treaty of Berlin was signed. Overall, the Congress of Berlin had achieved its goals. On a short term basis, the Congress had stopped an impending war between Russia and Great Britain. Also, the meeting had altered the unpopular Treaty of San Stefano, and thereby stopping Russia's attempt to decide the Eastern Question unilaterally.

In looking at the decisions made at Berlin, especially the division of Bulgaria, the Habsburg occupation of Bosnia-Herzegovina, limited gains by the Tsar and the Balkan states, combined with the English occupation of Cyprus, "The Congress of Berlin was humiliating and disastrous [for Russia]. It really appeared that Russia had fought a great and difficult war in order to secure advantages for Austria and England."125 In short, "Russian diplomacy had nothing to show but the retrocession of Southern Bessarabia and the acquisition of a strip of Armenia in return for a costly campaign." 126 These facts were reflected by the reception that the diplomats received at home.

Two days after the treaty was signed "the British plenipotentaries returned to London where a triumphant reception awaited them. Prime Minister Disraeli declared that he had brought back "Peace with Honor'."127 Turkey had once again been put on an apparently firm footing.

125 Tbid., 163.

126 Tbid., 163.

127 Cecil, 295-296. 
Moreover, the British had denied the Three Emperors' League the opportunity of solving the Eastern Question alone. No doubt now existed that any serious alteration of the situation in the Balkans had to be approved in London as well. In fact, "whereas the Congress of Paris [1856] had destroyed 'The Crimean Coalition', the Congress of Berlin almost recreated it."128 The disastrous impact that the Congress had on the Dreikaiserbund was exactly what Disraeli hoped for. Since the Berlin Memorandum of 1876 , the prime minister had looked for ways to lessen the effectiveness of the alliance, and if possible, to put its partners at odds with one another. Later, Disraeli wrote

next to making a tolerable settlement for the Porte [Sultan], our great objective was to break up, and permanently prevent, the alliance of the three empires, and I maintain there never was a general diplomatic result more completely effected. 129

On the negative side

the resounding achievement of 1878 weakened the effectiveness of British policy in the long run; for it led the English public to believe that they could play a great role without expense or exertion...[or] without finding an ally. ${ }^{130}$

Of course this effect on English attitudes would not be known for several years. So for a period immediately after the Congress, the meeting was undoubtedly judged a great success for Great Britain.

128 Taylor, 258.

129 Buckle, 367. The Prime Minister made this comment in a letter written in November 1880.

130 Taylor, 250. 
Austria-Hungary also came out of the Congress in a strengthened position, as it gained the right to occupy the two desired provinces, as well as being granted a strong voice on the control of the Danube River, especially at the Iron Gates. Nevertheless, Andrassy received much criticism at home.
Although the treaty was ultimately ratified, the campaign [in Austria-Hungary] against Andrassy in the press, the court, and in both parliaments finally made his position untenable. Opposition to his foreign policy was particularly strong in Hungary, when the occupation was objected to...[because it] was believed [it] would accrue to the Slav element in the empire. ${ }^{131}$

On top of this, the occupation of Bosnia-Herzegovina was not handled with great efficiency, despite coming to a full agreement on the occupation with the Sultan in April, 1879. Habsburg armies were met with resistance, and this caused Austro-Turkish relations to suffer. With the additional Slavs now coming under Habsburg control, "both German and Magyars saw only the potential threat to their predominance within the Dualist [Ausgleich] structure."132 Eventually, all of these criticism pushed Andrassy to resign his post as Austrian Foreign Minister in August, 1879.

For Bismarck, the Congress went about as well as could be expected. He worked hard to keep the meeting from falling apart, and he was given credit by the other diplomats for running the sessions in a speedy and business-like manner. ${ }^{133}$ Furthermore, his idea of partitioning the Ottoman Empire was adopted by the other powers as a way to end the state

131 Medlicott, 263.

132 Bridge, 98.

133 Cecil, 295. 
of anarchy that had persisted in many parts of the Empire, and the partition was seen as a method of preserving European peace. Bismarck strongly believed that he did the best he could by securing for the other members of the Dreikaiserbund their most fundamental goals at the Congress. He knew that Russia had to have Bessarabia, some gains in Armenia, and the creation of at least some sort of Bulgaria. At the same time, he was also aware that Austria-Hungary needed to prevent a dangerous situation from developing in the Balkans. In principle, he was exactly right, but, perhaps, he did not fully comprehend the true feelings of the others, especially Russia. Instead of looking at what they received, the Tsar, Gorchakov, and the Pan-Slavs saw only what they did not get. It was this group who felt that their costly war against Turkey had gained more for England and the Dual Monarchy than themselves. In looking for reasons for this outcome, Gorchakov put the blame on Bismarck, claiming Bismarck had backed Austria-Hungary on all the important issues. However, in looking at the decisions made at the Congress, it appears that Russia received about as much as was possible. For "Russia was also negotiating on the assumption that she could not resort to war, and Bismarck was quite prepared to give her the full benefit of his diplomatic skill and influence."134 The whole point behind Bismarck's policy of partitioning Turkey was to divide it in an equal fashion, and not give any one country a dominant position. In fact, that was the whole idea behind the need to change the unrealistic Treaty of San Stefano. If Russia intended to try to get any more than she did at Berlin, then she would have had to do it through war with Britain and, probably, Austria-Hungary (perhaps even 
against some other countries such as Italy). No one, not even Bismarck, could have obtained more for Russia than they received peacefully in the Treaty of Berlin. If Bismarck had pushed for any more, it would have made him appear biased towards Russia, and probably isolated Germany with Russia. This was the last thing that Bismarck wanted to do. Instead, Bismarck was strongly convinced that he got what he could for the Tsar, and even if he had pressed for more, it certainly would have been turned down by the other powers at the Congress.

The important point is, however, that this was not how the Tsar and many other top Russian officials saw it. They were very displeased by the outcome at Berlin. Perhaps, as we shall see, that it was this attitude that changed the course of history. 


\section{CHAPTER VI}

\section{REACTION TO THE TREATY OF BERLIN AND THE FORMATION OF THE DUAL ALLIANCE}

Though Russian officials knew before the Congress that the San Stefano pact could not be saved, and though they had made agreements with England and Austria-Hungary before the Congress on border compromises, many Russians, especially those who harbored Pan-Slavic ideals, thought that Russia had been humiliated at Berlin by their supposed friend. Russians saw that "Bismarck started by backing Austria wholeheartedly at the Berlin Congress, meeting all her demands... where Russia had spent thousands of lives and millions of pounds, Austria spent only ink and paper."135 In reality,

the [Russian] diplomats, who were anxious to exonerate themselves of responsibility, found it much more convenient to lay the blame on Bismarck, who owed Russia so much and had done so little to help her out...[so that] the Tsar was convinced that the whole meeting had been 'a European coalition against Russia under the leadership of Prince Bismarck.'136

This attitude went beyond limited Russian government circles. Later, the Paris correspondent for The London Times wrote an article in November, 1878, entitled: "The Kaiser Has Forgotten His Promise of 1870."137 What the

135 Taylor, 255.

136 Langer, 172.

137 Ibid., 251. 
correspondent was referring to, is the neutral role that Russia played during the 1870-1871 Franco-Prussian War, which allowed Prussia to complete German unification. Kaiser Wilhelm I told Tsar Alexander II that he would never forget this, and implied that Germany would someday pay her back. ${ }^{138}$ Thus, in the Tsar's eye, at the time when Russia needed her most, Germany abandoned her before all the Great Powers to see. The Tsar did not hold back his anger.

In August 1878, Alexander II sent Wilhelm I two very stern letters. In these letters, the Tsar complained that despite Russia's long-time friendship and devotion to Germany, she had not supported Russia at her time of need, and that now, the Tsar could not guarantee peace between the two nations. 139 In the meantime,

the newspapers of St. Petersburg and Moscow indulged in violent recriminations with those of Berlin...[and] in the reorganization and redistribution of the Russian armies that followed the war with Turkey, the troops stationed in Poland were strengthened to an extent that excited alarm in Germany. ${ }^{140}$

Bismarck felt suddenly threatened by an angry and emotionally charged neighbor, one that had tremendous strength. Rumors persisted of a Russian-French alliance, or a Russian-Italian alliance. This rapidly developing crisis was critical into pushing Bismarck to what had already

138 Ibid., 251.

139 Ibid., 250-251. This is a paraphrased version of Alexander II's letters. See this text for the letters in full.

140 Archibald Cary Coolidge, The Origins of the Triple Alliance (New York: Charles Scribner's and Sons, 1917), 154-155. 
been proposed--a military alliance between Imperial Germany and the Austro-Hungarian Empire.

Austrian Foreign Minister Count Julius Andrassy had first formally proposed such an alliance as early as 1872 , and, instead, had to settle for the much weaker Three Emperors' League between Germany, Russia, and the Dual Monarchy. Bismarck had declined Andrassy's offer in 1872, as a military alliance, especially against Russia, was then not necessary for Germany. However, times had changed, and the Russian reaction to the outcome at Berlin was indeed very hostile. Secondly, Austrian officials who were not pleased with Andrassy's performance at Berlin, forced his resignation. Vienna's pro-German policies, characterized by Andrassy, seemed threatened. With these factors in mind, a pact with AustriaHungary seemed to Bismarck to ensure close relations with the Dual Monarchy. Talks began in September, 1879, and before the Austrian foreign minister's resignation became effective, Bismarck and Andrassy came to a quick agreement. After only two meetings, the historic pact was finally signed on October 7, 1879.141

The actual treaty itself was fairly straightforward, as perhaps it reflected the rapid development of heightened tensions. Written in five articles, the pact made the following stipulations. ${ }^{142}$ First, if one of the two

141 This is the date when the pact was given formal approval by the Kaiser. The actual signing occurred on September 24, and then went through a review in Berlin, which will be discussed shortly. For more, see Coolidge, 165-172.

142 Most of my sources have the pact in five articles, although one has it in three. Perhaps it is just a matter of how the authors divided the agreement. See Coolidge, 219-221. 
empires were attacked by Russia, then the other party was bound to assist with a full military force, and the conclusion of peace would come only with mutual consent. Secondly, if one of the two powers were attacked by another force, the other party would respect neutrality. However, if that force was supported by Russia, then the other power would then be required to assist with a full military force. Also, the treaty was to cover a five-year period. One year before it was due to expire, the parties would analyze whether the conditions existed for a renewal. If no formal renewal talks were held, then the treaty would be considered extended for a three-year period. ${ }^{143}$ Furthermore, the treaty was to remain secret, unless mutually decided upon. However, if Russia were to continue its threatening mood, then the Tsar was to be warned that an attack on one power was considered an attack on both. And lastly, the treaty was to be validated by the two sovereigns, and would be ratified within fourteen days of their signatures. 144 Outside of this, the alliance had two simple objectives, "first, the defense of the status quo created by the Berlin Congress, and secondly, a mutual insurance against Russia."145 Yet it should be noted that while the specific contents of the treaty were secret, enough information was released on the treaty so that the Great Powers would generally know that such an

143 "Not until the year 1907 was the special agreement made whereby it was henceforth to be automatically extended at the end of each three-year term." Dr. Alfred Franzis Pribam, The Secret Treaties of AustriaHungary, 1879-1914 (Cambridge, Massachusetts: Harvard University, 1920), 7.

144 Ibid., 25-31. The part on guaranteeing neutrality in the face of a third party invasion was written by Germany, to make sure that Vienna would not help Paris in case France tried new aggressions.

145 Korff, 95. 
alliance existed between Germany and Austria-Hungary. For the treaty would not act as a deterrence if the other Great Powers, especially Russia, did not know something about it. But unknown to the two German empires at the time,

the Austrian-German Treaty, from October, 1879, to the outbreak of the World War, [would] constitute the basis of action of the Central Powers in all questions of foreign policy, most especially as concerns their relations to Russia. ${ }^{146}$

Not even Bismarck could have foreseen in 1879 the treaty's eventual significance.

The treaty received two completely different reviews within the German government. Bismarck was very enthusiastic. He was received by cheering crowds at home and in the Dual Monarchy, as the alliance struck a very close accord with German nationalists, conservatives, Southern Germans, and Catholics. Bismarck used this support as an argument for the 1879 alliance. ${ }^{147}$ Despite Bismarck's determination to form the alliance, which will be more fully analyzed later, he received stiff opposition from Kaiser Wilhelm I.

The Kaiser found it almost impossible to sign a military alliance against the Tsar, his friend and cousin. The sovereigns had just recently come together for a meeting on September 3, 1879 in Alexandrovo (in Russian-controlled Poland) to discuss the tensions and misunderstandings. With this candid meeting still fresh in his mind, Wilhelm I believed that a military pact against Russia would be seen as a

146 Pribam, 6.

${ }^{147}$ Bismarck, 282. 
betrayal of their September discussions. If there was to be any military agreement, then it should be three-way alliance with Russia included. Wilhelm even threatened to abdicate rather than agree to such a pact.

However, Bismarck was just as convinced that the alliance was justified, and he also threatened to resign. Since the chancellor had played such a prominent role at the Congress of Berlin, Wilhelm I could ill afford to have him leave now, and have the complicated Berlin Treaty supervised by someone who was inexperienced. Furthermore, Bismarck was supported by all the Kaiser's main diplomatic and military advisers. Even the Crown-Prince took the chancellor's viewpoint. Under such pressure, Wilhelm finally, but reluctantly, endorsed the alliance. 148 The only concession that the Kaiser obtained was that the treaty would be secret, and he would inform the Tsar himself as to the scope of the treaty. 149

The reaction of most other powers to the Dual Alliance was very favorable. British Foreign Secretary Lord Salisbury, in a speech in Manchester in October 1879, called the news of the pact "good tidings of great joy."150 This reflected the anti-Russian feeling that existed in the west after the Tsar's threatening actions during the Russo-Turkish war, and later following the Congress of Berlin. This corresponded to Bismarck's prediction that the alliance would be warmly received, especially by England, which had very close relations with both Vienna and

148 For reading the discussion on this, see: Bismarck, 285-286.

149 Coolidge, 170-172.

150 Ibid., 173. Perhaps this statement was made because the Dual Alliance signified an obvious split between the members of the Dreikaiserbund, which was one of Prime Minister Disraeli's major goals since the start of the Balkan uprisings. 
Berlin. In fact, Austria continuously tried to persuade the British that they should join the alliance. In the opinion of Heinrich Haymerle (Austrian Foreign Minister after Andrassy), "a coalition of central powers with England would maintain peace, for it would be so strong that no other grouping would dare to challenge it."151 But Bismarck was afraid that such an alliance would be too threatening to Russia, so "his advice to Haymerle was to...do enough to maintain British friendship."152

However, it was not just heightened tensions that pushed Bismarck to sign the Dual Alliance. After the Congress, Bismarck knew that a pact of some kind was necessary in order to maintain German security. Lacking any natural barriers to invasion, Bismarck saw Germany's newlywon position of strength and size as still uncertain. Thus, between the Berlin Congress and the alliance's approval, he made a very thorough analysis on his options--should he ally with Russia or Austria?153 Those were his main choices. What were the advantages and disadvantages of each? He was well aware of the importance of his decision, for it would likely signal Germany's direction in foreign affairs for many years to come.

Bismarck gave very serious consideration to creating a military alliance with Tsarist Russia. In fact, the Russian Ambassador to London, Count Peter Shuvalov, had proposed such an agreement just before the Congress of Berlin. Bismarck declined the offer then, and after the

151 W. N. Medlicott, Bismarck, Gladstone, and the Concert of Europe (London: The Athlone Press, 1956), 43-44.

152 Ibid., 63.

153 The chancellor goes through this review in his memoirs; Bismarck, 276-282, 286-296. 
Congress, the chancellor maintained the same reasoning for not combining with Russia. ${ }^{154}$ From a German point of view in 1879, Bismarck's judgment was excellent. The chancellor believed that by an alliance with the larger Russia, Germany would have automatically put herself in a second-class status to the naturally dominant and rather adventurous power. Furthermore, the Tsar might use the situation to his advantage, requiring Germany to join in costly wars in the Balkans, Persia, or in the Far East, none of which were in Germany's interests. Furthermore, given Germany's secondary role as an ally, the Tsar might dissolve the treaty at any time, perhaps even during a war. And since Russia's relations with the west were not good in 1878 , especially with England and Austria-Hungary, Germany would be in the position of isolating herself with Russia, giving the Tsar even more power and influence over Germany. Bismarck knew, too, that a German-Russian alliance would inevitably be directed against Austria-Hungary, and the Dual Monarchy would as a consequence be forced to go to France for an alliance of their own. This possible Paris-Vienna connection, or "Catholic Coalition" as Bismarck called it, was the chancellor's worst nightmare. It was not a far-fetched possibility. France and Austria had mutual interests, for they both might want to settle scores with Germany (for the wars of 1871 and 1866 respectively). Bismarck knew that such an alliance would be a

154 Bismarck, 260. Even after the Congress, Shuvalov was interested in close ties with Germany, as he did not blame Bismarck for the Berlin Treaty. However, he was never completely successful in converting Tsar Alexander II to his viewpoint. 
grave threat, and, as long as this "Catholic Coalition" was possible, Germany could never feel safe. ${ }^{155}$

Moreover, Bismarck found Russian political decision-making too unpredictable, as a growing number of Pan-Slavists, led by the Russian Ambassador to Constantinople, General Nicholas Ignatiev, were involved. The Pan-Slavs dreamt of unifying all Slavic people under Russian leadership, with their further goal of restoring the seat of the Eastern Orthodox Church to Constantinople, whence it was forced to flee after the Turks took power. The Pan-Slavs had no love for Germany, and they certainly wanted to destroy the Dual Monarchy or, at least, liberate the Slavs from the yoke of Vienna. In fact, "a most characteristic trait of the Russian Pan-Slav movement; it was prompted much more by hatred of Germany than by love of Slavs." 156 Bismarck's distrust was not unjustified, as the Pan-Slavs had most strongly pushed for the RussoTurkish War of 1877 and were most upset by the Treaty of Berlin. Besides these political reservations, Bismarck found the growing revolutionary movement in Russia as potentially threatening to Germany, while at the same time, possibly making Imperial Russia an unstable ally.

For Bismarck the Tsarist regime was to be retained as a strong friend within the Three Emperors' League. This way, the "Three Northern Powers" could work together to maintain conservative principles while also cooperating to defeat Socialist and Liberal causes. In this way, the Dual Alliance, in Bismarck's eye, was designed to eventually make the

155 Ibid., 286-287.

156 Korff, 97. 
Dreikaiserbund stronger, possibly even an actual military alliance.

However, this view was not shared by Austria-Hungary. Andrassy "would not have anything to do with an agreement 'a trois' with Russia. Again, such a monarchical league would appear to be directed against France."157 Much of Bismarck's rationale for Austria-Hungary was the same as those in his decision against Russia, only reversed. Since France's defeat by Prussia in 1871, the Dual Monarchy had become increasingly proGerman. This had been exemplified by their choice of foreign minister in 1871, Count Andrassy. However, Austrian officials were not satisfied with Andrassy's performance during the Congress of Berlin. A new foreign minister, Baron Heinrich Haymerle, was named. Haymerle was a "cautious, unadventurous career diplomat...[and] he was determined to continue Andrassy's anti-Russian policy." 158 Bismarck wanted to encourage this obvious vote of confidence by allying with the Dual Monarchy. In this manner, Bismarck kept Vienna in the pro-German camp, and thus, avoided the "Catholic Coalition" from coming about.

Bismarck was right that the Dual Alliance would appeal to Germans on both sides of the border. The reception that Bismarck received in both countries proved the point. However, Bismarck was rarely the sentimental type. His choice of the Habsburgs as an ally was based on Realpolitik, one of Bismarck's trademarks. ${ }^{159}$

157 Bridge, 106.

158 Ibid., 108.

159 Bismarck, 274. "The questions of the popularity in Germany and the Monarchy are for me a secondary importance, and were only further justifications to consider for the eventual outcome." 
In considering Austria-Hungary, at least since 1875, it was becoming apparent that

Germany could not afford to see Austria completely defeated and deprived of her position as a Great Power. If that were to happen, the Habsburg Empire would undoubtedly be disrupted, and even if Germany were strengthened by the acquisition of the German provinces of the empire, she would find herself alone between the powerful Tsarist Empire on the one side and a vengeful France on the other. ${ }^{160}$

Since Russia posed a threat to Austria-Hungary, Bismarck saw the new alliance as assuring the government of the Dual Monarchy that it would have help in the face of a possible Russian attack. ${ }^{161}$ If a Russo-German alliance had been signed, then the Dual Monarchy would have almost certainly been partitioned at some time in the future, possibly after a very bloody war. Bismarck was not interested in such a scenario.

A strong element of Bismarck's reasoning rested on the conviction that he could use the treaty to restrain Habsburg ambitions. Although Russian designs in the Balkans were well known, the Dual Monarchy was not without their own. For Bismarck, his success in foreign policy "depended on his ability to so direct the Eastern Question as to avoid collision between Russian and Austro-Hungarian interests in the Orient."162 To prevent such a conflict, Bismarck emphasized the alliance's defensive nature, and that Germany would come to the aid of Austria-

160 Langer, 175-176.

161 Bismarck, 278. However, this threat seemed more a concern to Bismarck than to the Habsburgs. Perhaps it is because as early as 1876 , Russia had asked Germany to remain neutral in the event of a RussianAustralian conflict; Bismarck, 242.

162 Andrassy, Bismarck, Andrassy..., 18. 
Hungary, but not sacrifice Berlin's own interests. Thus, the pact was not a blank check to allow Habsburg meddling in the Balkans, but rather it was designed by Bismarck to retain the Dual Monarchy's security and status as a Great Power. For unlike a German-Russian alliance, any Berlin-Vienna pact placed Germany as the unquestioned dominant party, a position that Bismarck relished and one that he was intent on keeping.

Bismarck also saw other uses for the alliance. It was seen as a "stepping-stone towards a new Three Emperors' League," and before that came about officially, Russia's isolation would force the Tsar to rely on Germany as his mediator with other powers. ${ }^{163}$ The isolation of Russia would force the Tsar to come to a more realistic assessment of the Treaty of Berlin, and lead him back into Germany's camp. "Her [Russia's] choice of allies remained limited. Republican France was unacceptable...England as before could not be considered. There remained the two German courts."164 And as Bismarck envisioned, the Tsar once again did seek friendship with Berlin.

For the Dual Monarchy, the signing of the Dual Alliance was a major victory, the accomplishment of a goal which they had first proposed in the early 1870 's. The alliance gave them a strong position, and it boosted their prestige abroad, which had sagged since their 1866 defeat by Prussia. Obviously, tying themselves to the German Reich met with a great deal of

163 Bridge, 107.

164 Jelavich, $\underline{A}$ Century of Russian Foreign Policy..., 186. At this stage, Alexander II could not consider an alliance with France because of the major ideological differences. This attitude would prevail in St. Petersburg until 1894, which changed under different circumstances and a different Tsar, in part due to the need for loans that France supplied. 
enthusiasm, and it proved to the non-Germans of the Monarchy that Vienna had finally decided to abandon any lingering dreams of becoming involved again in German politics.

However, there were some differences of interpretation of the treaty between Berlin and Vienna. Austrian officials thought that the alliance gave them strength in their Southeast European pursuits rather than acting as a restraint on them. Furthermore, an obvious pro-Austrian viewpoint in Berlin implied that it would be a permanent relationship, making any further close ties between Russia and Germany impossible. Thus, while Bismarck saw the treaty as the first step towards a closer Three Emperors' League, Andrassy saw the Dual Alliance as "the tombstone of the Three Emperors' League."165 This explained Austrian reluctance to renew the League until 1881, as Austria-Hungary "saw few advantages for herself in the arrangement."166

Andrassy did obtain a major concession in the alliance before he agreed to it. Originally, Bismarck had wanted the Dual Alliance directed against both Russia and France. But "Andrassy had been scrupulously careful in the negotiations to avoid anything that might cast a cloud over his relations with London and Paris," and agreeing to a military alliance against France would have done just that. ${ }^{167}$ The Dual Monarchy had no serious quarrel with Paris, and saw no need to create one. This attitude disturbed Kaiser Wilhelm I. He did not understand why Germany had to

165 Bridge, 107.

166 Jelavich, A Century of Russian Foreign Policy..., 187.

167 Bridge, 107. 
help Austria in case of a Russian attack, but Austria did not have to aid Germany in case of an attack from France. However, Andrassy did not agree, and if there were to be an alliance, it "must be clearly directed against Russia."168 To this, Bismarck finally agreed, but with obvious disappointment.

The treaty caused the Tsar to discover just how isolated he really was. In fact

the need for a serious attempt at reconciliation with Germany had been realized by the Russian government before it received definite evidence of the AustroHungarian-German rapprochement,...[and it] supplied the primary reason for the new phase in Russian diplomacy. 169

The Tsar was aware that historically

the alliance of the three northern courts and the traditional Russian-Prussian link guaranteed the safety of the Russian western border,...as long as these agreements held...Russia was safe from the threat of a direct invasion by a hostile coalition. ${ }^{170}$

The Russians now realized that their reaction against the Treaty of Berlin and Bismarck was unrealistic, and that, it was futile to try to change the Berlin Treaty. Russia had been terribly weakened by the war with Turkey both militarily and financially. It was in no position to attack either Germany or Austria-Germany, especially if England intervened on behalf of the Dual Alliance. Thus, the Russians were forced to endeavor to resurrect the Three Emperors' League, an effort which succeeded in 1881.

168 Tbid., 106.

169 Medlicott, Congress of Berlin..., 385.

170 Jelavich, A Century of Russian Foreign Policy..., 291. 
A further guarantee of German friendship came with the Reinsurance Treaty of 1887, which pledged both Germany and Russia to maintain cordial and peaceful relations. Yet the 1879 treaty had left a permanent scar on relations between Berlin and St. Petersburg, since the treaty was "a proof that he [Bismarck] had given his preference to Austria; that the Russians had to assume a permanent anti-Russian bias in his policy as long as it remained in force."171 If Bismarck had wanted to show that he was not pro-Austrian at the Congress of Berlin, then the Dual Alliance seemed a contradiction. To renew the treaty only reinforced Russian suspicions of Germany's attitude. It is perhaps true that the initial signing of the Dual Alliance was not a mistake, as it did bring the Russians back into the fold. But it seems logical that the renewed Three Emperors' League in 1881 should have voided the Dual Alliance. How could the Dual Alliance powers truly have maintained close relations with Russia, if they also had a major military alliance directed solely at Russia? Few friendships, no matter their history or close ties, can function in such a shaky and tense status. Russia either should have been included in the military agreement in 1881 , or there should have been no alliance at all. Bismarck should have said to Vienna--either you accept a three-way military agreement with Russia, or there will be no alliance. Germany had that power, and Austria-Hungary would have been forced into a compromise. In this manner, no one would have received preferable treatment. Either both would have been included in the alliance, or none. But Bismarck was afraid of trying this approach, for fear that Vienna

171 Medlicott, Bismarck Gladstone, ..., 43-44. 
would ally itself with France instead. Therefore, Bismarck tried to balance his relations with Vienna, while also maintaining a tense friendship with Russia. This would not satisfy the Tsar forever.

In other respects, the Dual Alliance represents both the first modern permanent alliance between two Great Powers, and also significantly, the longest existing military pact before World War I. Of course, most of these facts were not realized in 1879 , but they must be considered, as "the October treaty was soon followed by further developments in Bismarck's alliance system, which defeated William Gladstone's dream of a united Europe."172 This destruction of the Concert of Europe, first created during the Congress of Vienna of 1815, showed Bismarck's theory on maintaining European peace. Bismarck's

philosophy of international life remained fundamentally combative and pessimistic, and he could discover no reliable basis for national survival other than the accumulation and maneuvering of superior force. ${ }^{173}$

In short, the Dual Alliance was the first sign that the peace of Europe depended on the threat of war, rather than on a mutual and equal cooperation for peace as envisioned in the Concert of Europe. This philosophy is the same theoretically as that which has dominated postWorld War II Europe, in the effort to maintain peace on the continent with the NATO and Warsaw Pact Coalitions, and the threat of "Mutual Assured Destruction."

And also unknown to Bismarck in 1879, the Dual Alliance would have eventually become a traditional part of European diplomacy in the

172 Medlicott, Bismarck, Gladstone,..., 2.

173 Ibid., 11. 
later Nineteenth and early Twentieth Centuries, since it lasted until 1918. Especially for Berlin, as the relationship between Germany and AustriaHungary formally set up in the treaty became their most dependable one in foreign affairs.

A main question still unsolved here is the question whether alliances necessarily cause counter-alliances. One can not say that it always does, but the Dual Alliance was unique, in that it was the first pact between two Great Powers signed in a time of peace. Thus, it can be said that the Dual Alliance started the pattern of alliances, which
were defensive or deterrent in nature, designed to supplement one's military power, deter aggression, and aid in defense in the event the deterrence failed. As in the Nineteenth Century, military preparedness and planning in advance were absolutely vital to the successful conduct of war. ${ }^{174}$

The rapid victories of Prussia over Austria in 1866 and France in 1871 showed that no longer could one wait until the war was under way before gaining an ally. The war might already be decided before an ally could be found. Offensive dominance in military technology made preparation a vital part of defense and strategy of the time. With the offensive weapons having such an advantage, the Dual Alliance, while pretending to be a pact for defensive security, actually posed an offensive threat to Russia.

This brings us to an important consideration: how did Tsarist Russia perceive the alliance? Especially, if it was a secret treaty, how did the Tsar know that it was only defensive in character? Though the alliance was secret, enough information about its existence was passed on to Prussia to

174 Jack S. Levy, "Alliance Formation and War Behavior, and Analysis of the Great Powers, 1495-1975," Journal of Conflict Resolution 25, no. 4 (1981): 606. 
make the Tsar worry about the treaty's exact contents and character. What might have been considered a defensive war for Germany or for the Dual Monarchy might not have been seen as that to Russia, or to anybody else for that matter (as in 1914). Thus, although the Dual Alliance was not intended to do so, it in fact created worse problems. The completion of the treaty reinforced Russia's suspicions that at the Congress of Berlin, Germany threw its complete support behind Austria-Hungary, and now with the 1879 treaty, Bismarck intended to continue that policy. Thus, it appeared that as long as the Dual Alliance was in existence, RussoGerman (and certainly not Austro-Russian) relations could never be truly good again. The Three Emperors' League or the Reinsurance Treaty were not enough--the Germans had made their choice, and in doing so, proved (by keeping the Dual Alliance) that Berlin did not trust the Russians. This development seems strange, as Bismarck always made sure that he had an option in choosing between Russia and the Dual Monarchy. This was one of the goals for Bismarck in creating the Dreikaiserbund. However, in signing the alliance, Bismarck himself destroyed that freedom of choice available to him in the Dreikaiserbund by siding with Austria-Hungary in 1879.

While alliances in general do not inevitably create rival groupings, the Dual Alliance of October 1879 "generated counter-alliances, which generated further mistrust and tensions, leading to an arms race, and the further polarization of the alliance structure."175 Despite the best effort of Russia to recreate close ties with Germany, they never felt totally safe. Eventually, the Tsar's regime felt compelled to look for another friend to 
protect against this threat on the crucial western border. Although many other things had to occur between 1879 and 1894 to prompt the Romanovs to turn to the French Republic, Russia finally completed this step with their alliance with France in 1894. This was just exactly what Bismarck had wanted to avoid. As a result, the stage was set for a European conflict. 


\section{CHAPTER VII}

\section{CONCLUSION}

Although the Dual Alliance of October 1879 between Imperial Germany and the Austro-Hungarian Empire is an early factor in the origins of the First World War, the alliance played an important part in the roots of the war. The Congress of Berlin of 1878 showed that as long as a strong Germany existed, Berlin's relations with Russia would be much different and more difficult than before unification. Even so, close relations were not impossible. However, from the Russian perspective, Chancellor Bismarck took up and supported the Austrian (and English) cause at the Congress. Though Tsar Alexander II over-reacted to the Congress, it was Germany's decision to sign the Dual Alliance, thereby creating the first obvious split in relations between the Three Northern Powers. If the Tsar acted hastily in his response to the Treaty of Berlin, perhaps Bismarck did so too, in October of 1879 . Since the treaty was regularly renewed thereafter, relations between the three empires steadily drifted further apart. As it then eventually became apparent that Germany was going to remain pro-Austrian, the Russians had little choice but to go to Paris in 1894, especially as German military and economic strength grew enormously in the 1890 's. Such a French-Russian Alliance would not have been necessary without the existence of the Dual Alliance. If Bismarck made an especially serious mistake concerning the Dual Alliance, it consisted in the fact that the treaty was always renewed without the 
addition of Russia. If that had come about, then perhaps the course of history might have been quite different. The "Great War" of 1914-1918 might have been avoided, or, at least, fought with different alliance systems.

But the question is, would the Dual Alliance have come about without the Congress of Berlin? Possibly, but not as early as 1879 . This can be said by considering the relations between the Three Northern Powers between 1871 (the unification of Germany) and 1878. Though there were some significant differences between the three, in particular, between Russia and Austria-Hungary, relations had never been so tense as to bring the situation to a war. Rumors of a possible war were one thing, but actual preparation for war was another. The Congress of Berlin, however, represented the first time that Russia went beyond discussing a war, and actually started serious preparations for hostilities. Thus, the Congress of Berlin appears to be the key factor that brought on the eventual split between Germany and Russia concerning the place of Austria-Hungary in Balkan politics. For it was Austria-Hungary that brought on the problems between Berlin and St. Petersburg. But for the Dual Monarchy, there would have been no serious quarrels between Germany and Russia, at least none severe enough to threaten relations. Before the Congress, Bismarck had been able to keep the other two powers reasonably content in the Balkans. As the 1878 meeting neared, Bismarck had realized that the Habsburg Monarchy presented a more stable ally, but he still participated in the Congress with the intent to do what he could for Russia. Since the German chancellor found at the Congress that Russia could never be fully satisfied, and after the Tsar threatened war, Bismarck concluded he had no choice 
but to secure the position of both Germany and the Dual Monarchy with a military alliance. This decision would dominate German foreign relations until 1918.

Actually hostilities did not actually erupt between the three states until 1914, a prime point of origin for the problems in 1914 began with the 1878 Congress of Berlin. If historians are looking for a root cause for "The Great War", then the 1878 Congress of Berlin must be considered as one of the most crucial ingredients in the final decisions in August 1914. This fact, more than any other, is why the 1878 Congress of Berlin should be studied carefully as a true watershed in European diplomatic history. 


\section{REFERENCES}

Books

Andrassy, Count Julius. Bismarck, Andrassy and Their Successors.

Boston: Houghton Mifflin Company, 1927.

Whose Sin Is the World War? New York: New Era

Publishing House, 1915.

Baumgart, Winfried. Erträge Der Forschung-Vom Europäsichen Konzert zum Völkerbund. Darmstadt: Wissenschaftliche Buchgesellschaft, 1974.

Bismarck, Otto Fürst von. Gedanken und Erinnerungen. Zweiter Band. Stuttgart: J. G. Cottásche, 1898.

Bridge, F. R. From Sadowa to Sarajevo--The Foreign Policy of AustriaHungary, 1866-1914. London: Routledge and Kegan Paul, 1972.

Buckle, George Earle. Life of Benjamin Disraeli. 1876-1881. Vol. 6. New York: The MacMillan Company, 1920.

Cecil, Lady Gwendolen. Life of Robert Marquis of Salisbury, 1868-1880. Vol. 2. London: Hodder and Stoughton, 1926.

Clayton, G. D. Britain and the Eastern Question--Missolonghi To Gallipoli. London: University of London Press, Ltd., 1971.

Coolidge, Archibald Cary. The Origins of the Triple Alliance. New York: Charles Scribner's and Sons, Inc., 1917.

Craig, Gordon A. and Alexander L. George. Force and Statecraft-Diplomatic Problems of Qur Time. New York: Oxford University Press, 1920.

Duggan, Stephen Pierce Hayden. The Eastern Question-- $\underline{A}$ Study in Diplomacy. Vol. 24, no. 3. New York: AMS Press, 1970, reprint 1902.

Hamerow, Theodore S. Otto von Bismarck--A Historical Assessment. 2d ed. Lexington, Massachusetts: D.C. Heath and Company, 1962; reprint 1972. 
Hillgruber, Andreas. Deutsche Grossmacht und Weltpolitik im 19 und 20 Jahrhundert. Düsseldorf: Droste Verlag, 1977.

- Die gescheiterte Grossmacht-Eine Skizze des Deutschen Reiches, 1871-1945. Düsseldorf: Droste Verlag, 1982.

Jelavich, Barbara. A Century of Russian Foreign Policy, 1814-1914.

Philadelphia: J. B. Lippincott Company, 1964.

The Ottoman Empire, The Great Powers, and the Straits Question, 1870-1887. Bloomington, Indiana: Indiana University Press, 1973.

Korff, Baron S. A. Russia's Foreign Relations During the Last Half Century. New York: The MacMillan Company, 1920.

Kos, Franz-Josef. Die Politik Österreich-Ungarns während der Orientkrise, 1874/5-1879. Cologne: Bohlau Verlag, 1984.

Langer, William L. European Alliances and Alignments, 1871-1890. New York: Alfred A. Knopf, Inc., 1956.

Latimer, Elizabeth Wormeley. Russia and Turkey in the Nineteenth

Century. Chicago: A. C. McClurg and Co., 1894.

Marriott, J. A. R. The Eastern Question--A Study in European Diplomacy. 4th ed., London: Oxford University Press, 1947.

Medlicott, W. N. Bismarck, Gladstone, and The Concert of Europe.

London: The Athlone Press, 1956.

The Congress of Berlin and After--A Diplomatic History of the Near Eastern Settlement, 1878-1880. 2d ed. Hamden, Connecticut: Archon Books, 1963.

Munro, Henry F. The Berlin Congress. Washington, D. C.: Government Printing Office, 1918.

Palmer, A. W. A Dictionary of Modern History, 1789-1945. London: The Cresset Press, 1962.

Plano, Jack C., and Olton, Roy. The International Relations Dictionary. New York: Holt, Rinehart and Winston, Inc., 1969.

Polchinger, Heinrich von. Also Sprach Bismarck 1870-1888. Zweiter Band. Wien: Verlagsbuchhandlung. Carl Konegen, 1911. 
Pribam, Dr. Alfred Franzis. The Secret Treaties of Austria-Hungary, 18791914. Cambridge, Massachusetts: Harvard University Press, 1920.

Rich, Norman. The Age of Nationalism and Reform, 1850-1890. 2d ed. New York: W. W. Norton and Company, 1977.

Rupp, George Hoover. A Wavering Friendship--Russia and Austria, 18761878. Cambridge, Massachusetts: Harvard University Press, 1941.

Seaman, L. C. B. From Vienna To Versailles. New York: Harper Row Publishers, 1963.

Seton-Watson, R.W. Disraeli, Gladstone, and the Eastern Question. New York: Barnes and Noble, Inc., 1962.

Simon, Edward. The Emperor William and His Reign. Vol. II. London: Remington and Co., Publishers, 1886.

Sontag, Raymond James. European Diplomatic History, 1871-1932. New York: Appleton-Century Crofts, Inc., 1961.

Stavrianos, L. S. The Balkans, 1815-1914. New York: Holt, Rinehart and Winston, Inc., 1963.

Stojanovic, Mihailo D. The Great Powers and the Balkans. Cambridge, England: Cambridge University Press, 1939; reprint 1968.

Taylor, A. J. P. The Struggle For Mastery in Europe, 1848-1918. Oxford, England: Oxford Clarendon Press, 1954.

Temperley, Harold and Lillian M. Pensam. ed. A Century of Diplomatic Blue Books, 1814-1914. "The Eastern Question Papers of The Disraeli Administration, 1874-1880." New York: Barnes and Noble, Inc., 1938; 251-257.

Journal Articles

Fryer, W. R. and B. Litt, "The Republic and the Iron Chancellor. The Pattern of French-German Relations, 1841-1890." Royal Historical Transactions 29 (1979): 169-185.

Gall, Lothar. "Die Europäischen Mächte und der Balkan im 19 Jahrhundert." Historische Zeitschrift 228 (1979) 3: 551-571.

Jelavich, Barbara. "Great Britain and the Russian Acqusition of Batum, 1876-1886." The Slavonic and East European Review 48 (1970) 110: 4466. 
"Russia and the Reacquisition of Southern Bessarabia, 1875-1878." Südostforschungen 28 (1969) 199-237.

Kissinger, Henry A. "A White Revolutionary: Reflections on Bismarck." Daedalus 97 (1968): 888-924.

Levy, Jack S. "Alliance Formation and War Behavior: An Analysis of the Great Powers, 1495-1975." Journal of Conflict Resolution 25 (1981) 4: 581-613.

Pflanze, Otto. "Toward A Psychoanalytic Interpretation of Bismarck." American Historical Review 77 (February-June 1972) 1: 419-444.

Rossetti, R. "Roumania's Share in the War of 1877." The Slavonic and East European Review 8 (1929/1930): 548-570.

Seton-Watson, R. W. "Russian Commitments in the Bosnian Question and an Early Project of Annexation." The Slavonic and East European Review 8 (1929/1930): 578-588.

Stein, Arthur and Brian Healy. "The Balance of Power in International History--Theory and Reality." Journal of Conflict Resolution 17 (1973) 1: 33-61.

Strakhovsky, Leonid I. "General Count N. P. Ignatiev and the Pan Slav Movement." Journal of Central European Affairs 17 (October 1957) 3: 223-235.

Sugar, Peter F. "The Southern Slav Image of Russia in the Nineteenth Century." Journal of Central European Affairs 21 (April 1961) 1: 4552.

Suppan, Arnold. "Bosnischer Aufstand und Orientkrise, 1875-1878." Österreichische Osthefte 18 (1976) 2: 189-191. 